\title{
Article \\ Prioritization of Mycotoxins Based on Their Genotoxic Potential with an In Silico-In Vitro Strategy
}

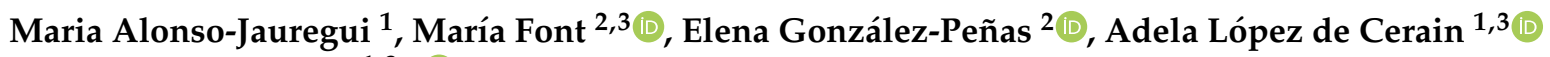 \\ and Ariane Vettorazzi $1,3, *$ (i) \\ 1 Department of Pharmacology and Toxicology, Research Group MITOX, School of Pharmacy and Nutrition, \\ Universidad de Navarra, 31008 Pamplona, Spain; malonso.17@alumni.unav.es (M.A.-J.); \\ acerain@unav.es (A.L.d.C.) \\ 2 Department of Pharmaceutical Technology and Chemistry, Research Group MITOX, School of Pharmacy and \\ Nutrition, Universidad de Navarra, 31008 Pamplona, Spain; mfont@unav.es (M.F.); \\ mgpenas@unav.es (E.G.-P.) \\ 3 IdiSNA, Navarra Institute for Health Research, 31008 Pamplona, Spain \\ * Correspondence: avettora@unav.es
}

Citation: Alonso-Jauregui, M.; Font, M.; González-Peñas, E.; López de Cerain, A.; Vettorazzi, A.

Prioritization of Mycotoxins Based on Their Genotoxic Potential with an In Silico-In Vitro Strategy. Toxins 2021, 13, 734. https://doi.org/10.3390/ toxins 13100734

Received: 29 July 2021

Accepted: 12 October 2021

Published: 19 October 2021

Publisher's Note: MDPI stays neutral with regard to jurisdictional claims in published maps and institutional affiliations.

Copyright: (c) 2021 by the authors. Licensee MDPI, Basel, Switzerland. This article is an open access article distributed under the terms and conditions of the Creative Commons Attribution (CC BY) license (https:// creativecommons.org/licenses/by/ $4.0 /)$.

\begin{abstract}
Humans are widely exposed to a great variety of mycotoxins and their mixtures. Therefore, it is important to design strategies that allow prioritizing mycotoxins based on their toxic potential in a time and cost-effective manner. A strategy combining in silico tools (Phase 1), including an expert knowledge-based (DEREK Nexus ${ }^{\circledR}$, Lhasa Limited, Leeds, UK) and a statistical-based platform (VEGA QSAR@), Mario Negri Institute, Milan, Italy), followed by the in vitro SOS/umu test (Phase 2), was applied to a set of 12 mycotoxins clustered according to their structure into three groups. Phase 1 allowed us to clearly classify group 1 (aflatoxin and sterigmatocystin) as mutagenic and group 3 (ochratoxin A, zearalenone and fumonisin B1) as non-mutagenic. For group 2 (trichothecenes), contradictory conclusions were obtained between the two in silico tools, being out of the applicability domain of many models. Phase 2 confirmed the results obtained in the previous phase for groups 1 and 3. It also provided extra information regarding the role of metabolic activation in aflatoxin B1 and sterigmatocystin mutagenicity. Regarding group 2, equivocal results were obtained in few experiments; however, the group was finally classified as non-mutagenic. The strategy used correlated with the published Ames tests, which detect point mutations. Few alerts for chromosome aberrations could be detected. The SOS/umu test appeared as a good screening test for mutagenicity that can be used in the absence and presence of metabolic activation and independently of Phase 1, although the in silico-in vitro combination gave more information for decision making.
\end{abstract}

Keywords: mycotoxins; in silico; SOS/umu test; genotoxicity; prioritization

Key Contribution: A strategy combining in silico tools; including an expert knowledge-based (DEREK Nexus ${ }^{\circledR}$ ) and a statistical-based platform (VEGA QSAR@), followed by the in vitro SOS/umu test; allowed us to classify in a time and cost-effective manner 12 mycotoxins based on their mutagenic potential.

\section{Introduction}

Mycotoxins (MTX) are low molecular-weight natural compounds produced as secondary metabolites by filamentous fungi, mainly Aspergillus, Penicillium and Fusarium. More than 300 compounds have been classified as mycotoxins; however, only a few have received attention as threats to human and animal health due to their toxic potential and worldwide contamination [1]. Indeed, at the EU level, only aflatoxins (AFs), ochratoxin A (OTA), patulin (PAT), deoxynivalenol (DON), zearalenone (ZEA), fumonisins (FUM), T-2 toxin (T-2) and HT-2 toxin (HT-2) are regulated in different foodstuffs [2]. Moreover, there is an increasing awareness of minimizing mycotoxin exposure [3]. The general population 
is widely exposed to mycotoxins, mainly through diet, as occurrence above a detectable level is considered to be up to $60-80 \%$ [4]. Furthermore, in the current context of climate change, mycotoxins might appear as an emerging risk [5], as new climate scenarios might modify the presence of regulated mycotoxins [6] but also might introduce emerging, and thus currently not regulated, forms [7]. In brief, there is a great diversity of mycotoxins that can contaminate food and feed, and therefore a variety of different toxicological effects to consider when prioritizing. For example, regarding DNA damage, some mycotoxins are known to be potent genotoxins (AFs) [8] and others seem to be clastogenic [9], while for others, their genotoxicity is unknown (such as, for example, 15-acetyldeoxynivalenol) [10]. Finally, humans are exposed to more than one mycotoxin. Several human biomonitoring studies conducted worldwide have demonstrated co-exposure to at least two mycotoxins; OTA + AFs being the most frequently analyzed mycotoxins in plasma (for a review, see [11]). Indeed, the combination of OTA + AFs together with AFs + FUM, DON + ZEA, and FUM + ZEA were the most observed combinations in cereals [12]. Data regarding their combined toxicity are still lacking or inconclusive, showing antagonist, additive or synergic effects depending on the tested species, cell model, or mixture [12,13].

Therefore, as the number of mycotoxins (including regulated and emerging/modified forms) and their possible combinations is very high, it is important to develop an efficient tiered strategy to prioritize the mycotoxins and their mixtures that should be first evaluated from a toxicological point of view [5]. Prioritization in a time- and cost-effective manner is pivotal for health-risk assessment of emerging risks.

Mycotoxins have numerous deleterious effects, including nephrotoxicity [14], hepatotoxicity [15], reprotoxicity [16], endocrine disruption [9], immunotoxicity [17], and intestinal toxicity [18]. The amount of resources and time necessary to characterize the toxicity could be reduced with prioritization strategies. One of the main health concerns for the general population is their toxicity at low concentrations and after long-term exposures [1]. In this regard, genotoxicity and carcinogenicity (Table 1) have been considered as important toxicological endpoints for mycotoxins, mainly due to the fact that aflatoxin B1 (AFB1), the first discovered mycotoxin, is considered to be one of the most potent human hepatocarcinogens known to date [19].

Table 1. Carcinogenicity (IARC classification) and mutagenicity data (Ames and SOS/umu tests) of mycotoxins ${ }^{\text {a }}$.

\begin{tabular}{llll}
\hline Mycotoxin & IARC Classification (Year) & Ames Test & SOS Test \\
\hline Aflatoxin B1 & Group 1 (2012) [8] & Positive [20-29] & $\begin{array}{l}\text { Positive [30-39] } \\
\text { Negative [40] }\end{array}$ \\
\hline Sterigmatocystin & Group 2B (1976) [41] & Positive [21,23-26,42] & $\begin{array}{l}\text { Positive [32,33,37,38,43] } \\
\text { Negative [40] }\end{array}$ \\
\hline Nivalenol & Group 3 (1993) [44] & No data & No data \\
\hline Deoxynivalenol & Group 3 (1993) [44] & Negative [25,45,46] & Negative [45] \\
\hline 3-Acetyldeoxynivalenol & No classification & Negative [25] & No data \\
\hline 15-Acetyldeoxynivalenol & No classification & No data & No data \\
\hline Fusarenon-X & No clasiffication & Negative [42] & No data \\
\hline T-2 toxin & Group 3 (1993) [44] & Negative [24,25,42] & Negative [30,33] \\
\hline HT-2 toxin & No classification & No data & No data \\
\hline Ochratoxin A & Group 2B (1993) [44] & $\begin{array}{l}\text { Negative [24,26,47-49] } \\
\text { Positive [50] }\end{array}$ & \begin{tabular}{l} 
Negative: [32,38] \\
Weak positive [33] \\
\hline Pearalitive [51]
\end{tabular} \\
\hline Fumonisin B1 & Group 3 (1993) [44] & Negative [24,25,52] & $\begin{array}{l}\text { Negative [30-33,38] } \\
\text { Positive [53] }\end{array}$ \\
\hline
\end{tabular}

${ }^{a}$ The most recent International Agency for Research on Cancer (IARC) classification for each mycotoxin is shown. To retrieve results regarding Ames Test and SOS/umu, the following search strategy was followed: (a) Pubmed search "[name of each individual mycotoxin] AND (ames OR sos OR "reverse mutation"). No filters were used; (b) Pubmed and Scifinder search: mycotoxin AND (sos chromotest OR sos umu test OR sos spot test OR sos microplate). No filters were used. Only articles presenting results of Ames Test (at least one Salmonella strain) or SOS tests of each individual mycotoxins were included for data extraction. 
The aim of the present paper is to present and validate a strategy to prioritize mycotoxins based on their genotoxic potential. For that purpose, two in silico tools (Phase 1) and one medium-throughput in vitro genotoxicity test (Phase 2) were used (Figure 1).
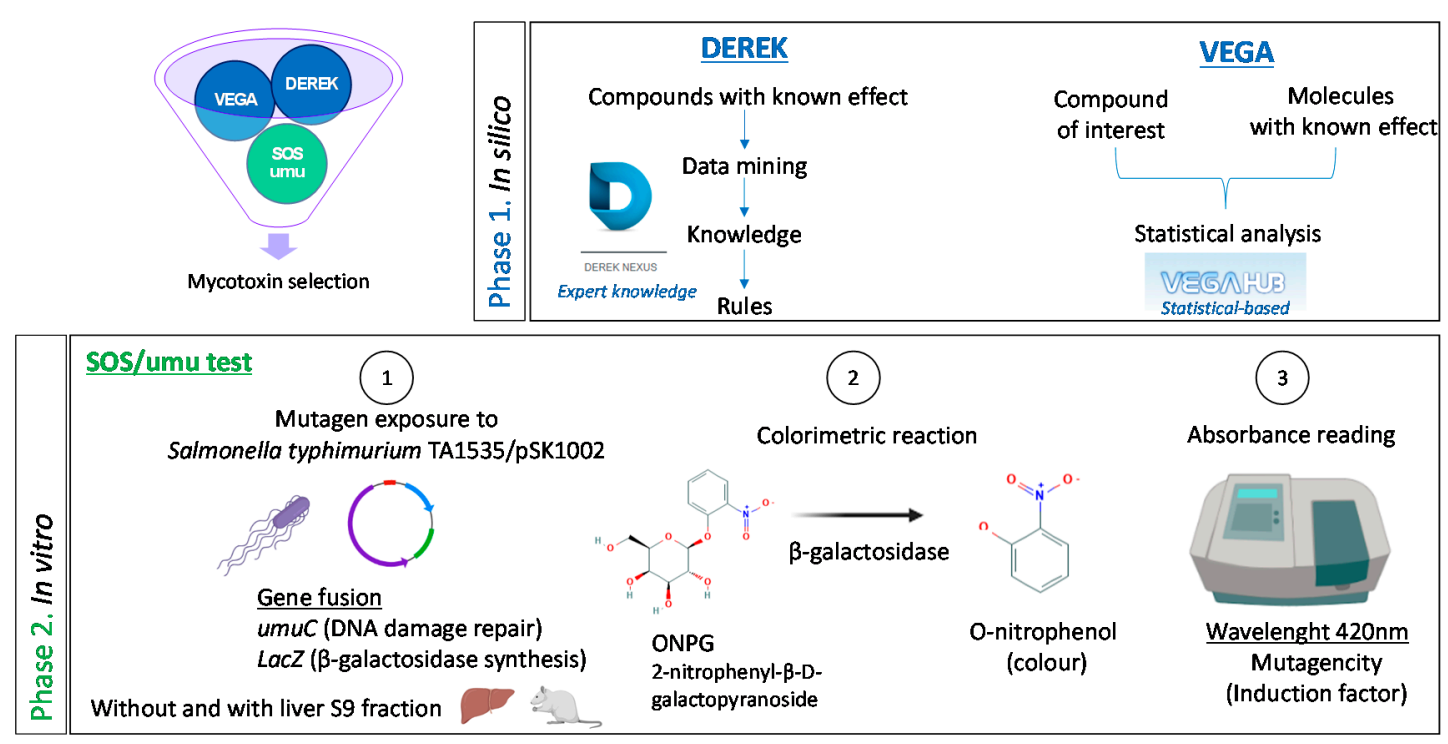

Figure 1. Strategy followed to prioritize mycotoxins based on their genotoxic potential. Phase 1 includes two different in silico tools: (i) DEREK Nexus ${ }^{\circledR}$ Lhasa Limited, Leeds, UK (commercial) that uses rule-based predictions based on expert-knowledge, and (ii) the VEGA QSAR@ Mario Negri Institute, Milan, Italy (free online platform) offering different models for statistical-based predictions. Phase 2 corresponds to the medium-throughput in vitro genotoxicity assay, the $\mathrm{SOS} / \mathrm{umu}$ assay, based on a colorimetric reaction.

Phase 1 was designed following ICH (International Conference on Harmonization of Technical Requirements for Pharmaceuticals for Human Use) M7 guideline for mutagenic assessment of impurities derived from drug development, which recommends the use of two complementary in silico methodologies: (i) expert rule-based and (ii) statisticalbased [57]. Thus, Phase 1 was performed using the predictive tool DEREK Nexus ${ }^{\circledR}$, a knowledge-based expert system for qualitative toxicity prediction, and VEGA QSAR@, a platform that offers different quantitative structure-activity relationship (QSAR) models. The objective of Phase 2 was to validate the results obtained in Phase 1 with an in vitro genotoxicity test. Normally, for genotoxicity testing of chemicals, a standard in vitroin vivo battery is recommended (ICH S2R1 guideline) [58,59]. This battery always includes the Ames test (TG OECD 471) [60] as a first mutagenicity assay for detecting gene mutations, followed by other in vitro tests for detecting chromosomal aberrations, such as the micronucleus test (TG OECD 487) [61]. Depending on the outcome of the in vitro tests, follow-up in vivo assays might be needed. The complete recommended strategy is time-consuming and needs large amounts of test item (e.g., around $1 \mathrm{~g}$ only for the Ames test). The amount of test item is indeed a bottleneck in the field of mycotoxins, as some new emerging/modified forms are not commercially available and are only synthesized in small amounts by some research groups. Additionally, the commercially available mycotoxins are expensive, and very often the standardized tests following Organisation for Economic Co-operation and Development (OECD) guidelines have not been carried out in their totality (e.g., not using the five recommended bacteria strains in the Ames test). Therefore, for Phase 2, the SOS/umu assay was selected. It is a medium-throughput assay for genotoxicity screening $[62,63]$, which allows us to evaluate the DNA damaging effect of several compounds (six per 96-well plate). It needs relatively small amounts of test item (around $2 \mathrm{mg}$ ), and results are available within two days. The test is carried out in Salmonella typhimurium TA1535/pSK1002 with and without metabolic activation (S9 mix). Salmonella typhimurium TA1535 incorporates a pSK1002 plasmid containing the umuC 
gene fused to a lac $Z$ reporter gene. The umuC gene is activated as part of the bacterial SOS response. In turn, this promotes the $\beta$-galactosidase activity associated with lac $Z$, which is assessed by a colorimetric reaction. The test was selected because a high degree of agreement with the standardized Ames test (TG OECD 471) has been found [64].

The strategy has been applied to 12 mycotoxins, including the well-characterized aflatoxin B1 (AFB1) and ochratoxin (OTA), an emerging mycotoxin (sterigmatocystinSTER) with some genotoxicity red flags in the literature, and other regulated mycotoxins such as deoxynivalenol (DON), zearalenone (ZEA), fumonisin B1 (FB1), T-2 and HT-2 toxins. Moreover, some modified forms or structurally related metabolites have also been included: 3-acetyldeoxynivalenol (3ADON), 15-acetyldeoxynivalenol (15ADON), nivalenol (NIV) and fusarenon-X (F-X). For the analysis and reporting, mycotoxins were clustered based on their chemical structure.

\section{Results}

The genotoxic potential was characterized in two phases, in silico (Phase 1) and in vitro (Phase 2). Before Phase 1, a structural activity relationship (SAR) analysis focused on Absorption, Distribution, Metabolism, Excretion and Toxicity (ADMET) descriptors was carried out for all the mycotoxins (for details, see Supplementary Data, Section 1). In Phase 1 , all the mycotoxins were analyzed with DEREK Nexus ${ }^{\circledR}$ and VEGA QSAR@. The in vitro assessment (Phase 2) was carried out with a SOS/umu test. For data reporting, the mycotoxins were clustered into three different groups based on their chemical structure (Figure 2).

\subsection{Structural Analysis}

From a structural point of view, the mycotoxins hereby studied (Figure 2) can be grouped into three different groups.

\subsubsection{Group 1. Furo[2 ,3-b]benzofuran derivatives, AFB1 and STER}

AFB1 (Figure 2a) is an aflatoxin with a tetrahydrocyclopenta[c]furo[3', $\left.2^{\prime}: 4,5\right]$ furo[2,3h]chromene skeleton with oxygen functionality at positions 1,4 and 11, whereas STER (Figure $2 b$ ) is an heteropentacyclic derivative whose skeleton comprises a xanthene ring system ortho-fused to a dihydrofuranofuran moiety; in both structures the central scaffold furo[2,3-b]benzofuran can be recognized (Figures $3 a$ and 4 ).

2.1.2. Group 2. 1,5-Dimethylspiro[8-oxatricyclo[7.2.1.02,7]dodec-5-ene-12,2'-oxirane] derivatives: NIV, DON, 3ADON, $15 \mathrm{ADON}, \mathrm{F}-\mathrm{X}, \mathrm{T}-2$ and HT-2 (trichothecenes)

Taking as reference the structure of NIV (Figure 2c), (1S,2R,3S,7R,9R,10R,11S,12S)-3,10,11trihydroxy-2-(hydroxymethyl)-1,5-dimethylspiro[8-oxatricyclo[7.2.1.02,7]dodec-5-ene-12,2'-ox irane]-4-one, removing the $\mathrm{OH}$ group in position 11 leads to DON (Figure 2d). The acylation of $\mathrm{OH}$ in position 3 of DON leads to $3 \mathrm{ADON}$ (Figure 2e), whereas the acylation of $\mathrm{OH}$ located at 15 position leads to $15 \mathrm{ADON}$ (Figure $2 \mathrm{f}$ ). The acylation of $\mathrm{OH}$ located in position 3 of NIV leads to F-X (Figure 2g). The structural modification of the 2-hydroxymethyl group of NIV to 2-acetyloxymethyl, together with the acetylation of the $\mathrm{OH}$ moiety located at 11 and the modification of 1,5-dimethylspiro[8-oxatricyclo[7.2.1.02,7]dodec-5-ene-12,2'oxirane]-4-one (Figure 3b) moiety to 1,5-dimethylspiro[8-oxa tricyclo[7.2.1.02,7]dodec-5ene-12,2'-oxirane]-4-yl] 3-methylbutanoate moiety leads to T-2 toxin (Figure 2h). The hydrolysis of acyl moiety located at position 3 leads to HT-2 (Figure 2i).

\subsubsection{Group 3. Structurally Unrelated Toxins, OTA, FB1 and ZEA}

OTA (Figure 2j) is a derivative resulting from the formal condensation of the amino group of L-phenylalanine with the carboxy group of (3R)-5-chloro-8-hydroxy-3-methyl-1oxo-3,4-dihydro-1H-2-benzopyran-7-carboxylic acid. 

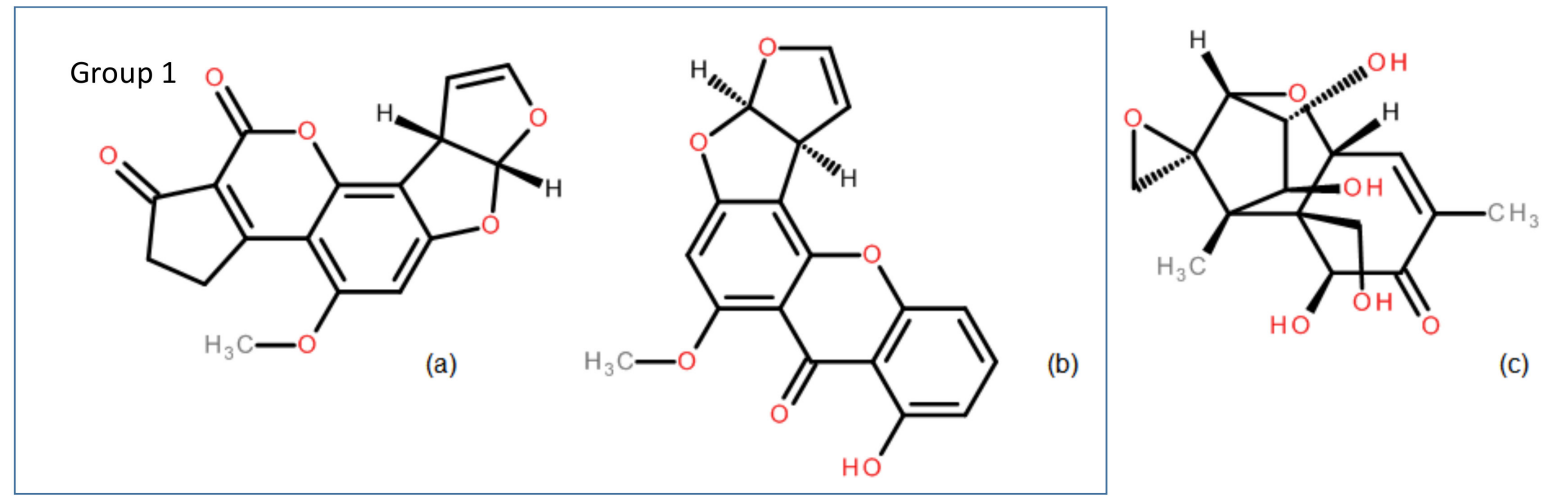

(c)

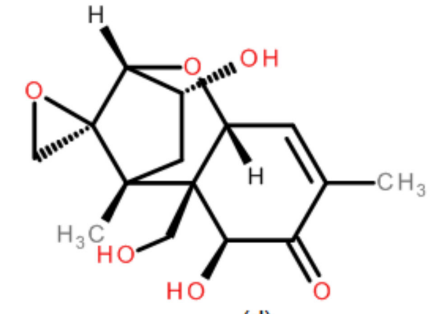

Group 2

(d)

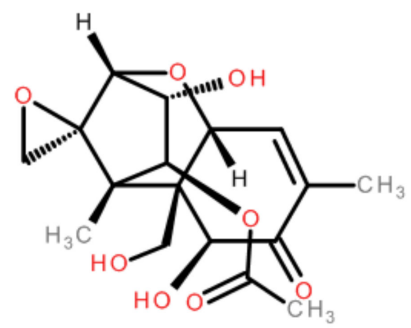

(g)

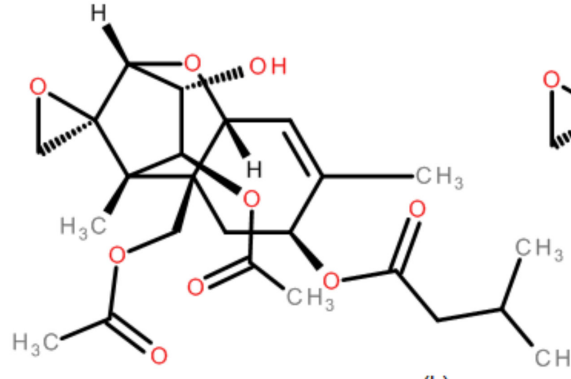

(h)

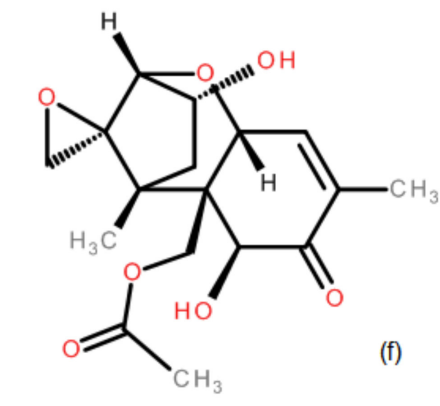

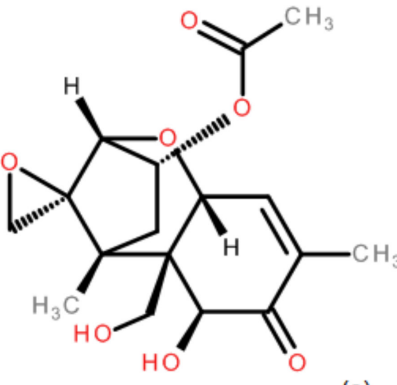

(e)

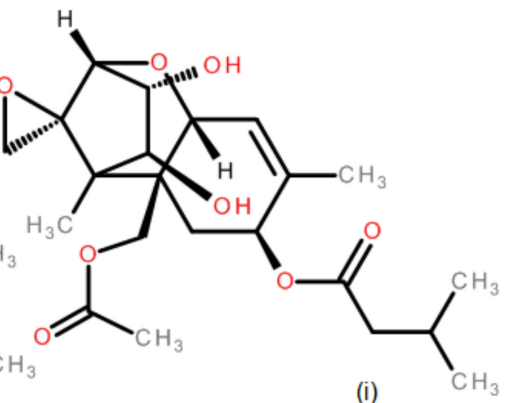

(i)<smiles>CCCC[C@H](C)[C@H](OC(=O)C[C@H](CC(=O)O)C(=O)O)[C@@H](C[C@@H](C)C[C@H](O)CCCC[C@H](O)C[C@H](O)[C@H](C)N)OC(=O)C[C@H](CC(=O)O)C(=O)O</smiles>

Figure 2. Structure for analyzed mycotoxins. Group 1: (a) AFB1; (b) STER; Group 2 (trichothecenes): (c) NIV; (d) DON; (e) 3ADON; (f) 15ADON; (g) F-X; (h) T-2; (i) HT-2 and Group 3: (j) OTA; (k) FB1; (1) ZEA. 
<smiles>C1=C[C@H]2OC=C[C@H]2O1</smiles>

(a)

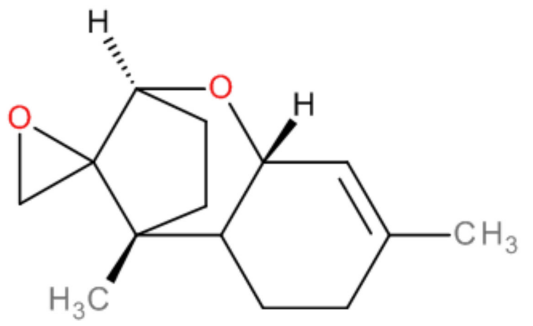

(b)

Figure 3. Structural scaffolds (a) for Group 1: furo[2,3-b]benzofuran (b) for Group 2: 1,5-dimethylspiro[8-oxatricyclo[7.2.1.0 2,7]dodec-5-ene-12,2'-oxirane].<smiles>O=C1CCC2=C1C(=O)OCC2</smiles>

(a)

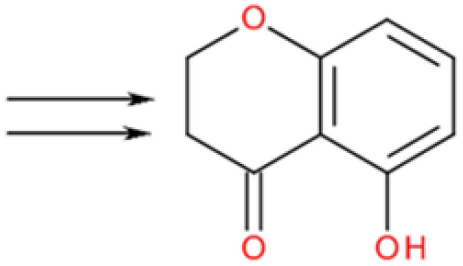

(b)

Figure 4. Structural variation (a) 3,4,5,6-tetrahydrocyclopenta[c]pyran-1,7-dione, AFB1 (b) 5hydroxychroman-4-one, STER (see text for details).

FB1 (Figure 2k) is a diester derived from the condensation of the 1-carboxy groups of two molecules of propane-1,2,3-tricarboxylic acid with hydroxyl groups located at positions 14 and 15 of $(2 S, 3 S, 5 R, 10 R, 12 S, 14 S, 15 R, 16 R)-2$-amino-12,16-dimethylicosane-3,5,10,14,15pentol.

ZEA (Figure 21) is a macrolide comprising a fourteen-membered lactone fused to 1,3-dihydroxybenzene.

\subsection{In Silico Toxicology (Phase 1)}

Tables 2 and 3 show detailed results obtained with DEREK Nexus ${ }^{\circledR}$ and VEGA QSAR@, respectively.

\subsubsection{Group 1 (AFB1 and STER)}

AFB1 and STER had similar pattern predictions with DEREK Nexus ${ }^{\circledR}$, related to their structural similitudes. In fact, the presence of a bisfuranoid moiety (Alert 201) and an alkyl-aldehyde precursor (Alert 306) can be considered as a potential toxophore. Therefore, plausible mutagenicity in vitro (in both bacteria and mammalian cell models) and chromosomal aberrations in vitro were retrieved. The non-specific genotoxicity in vitro was also considered as plausible, while no predictions were obtained for chromosome damage in vivo for both mycotoxins (Table 2).

AFB1 also has an $\alpha, \beta$-unsaturated ketone moiety that implies a specific alert (309), a potential toxophore, which reinforces positive genotoxic potential for this toxin.

Regarding VEGA QSAR@ outcomes, all experimental outputs agreed on AFB1 mutagenicity, for which information about its experimental mutagenicity was detected (see Table 3). All predictions showed positive outputs with good reliability (See Table 4). 
Table 2. DEREK Nexus predictions for mutagenicity of analyzed mycotoxins (alerts are shown as displayed in DEREK Nexus ${ }^{\circledR}$ ).

\begin{tabular}{|c|c|c|c|c|c|c|c|c|c|c|c|c|}
\hline \multirow{3}{*}{ Ref } & \multicolumn{4}{|c|}{ Mutagenicity In Vitro } & \multirow{2}{*}{\multicolumn{2}{|c|}{$\begin{array}{c}\begin{array}{c}\text { Mutagenicity } \\
\text { In Vivo }\end{array} \\
\text { Mammal }\end{array}$}} & \multicolumn{4}{|c|}{ Chromosome Damage (Mammal) } & \multicolumn{2}{|c|}{$\begin{array}{c}\text { Non-Specific } \\
\text { Genotoxicity } \\
\text { In Vitro }^{d}\end{array}$} \\
\hline & \multicolumn{2}{|c|}{ Bacterium } & \multicolumn{2}{|c|}{ Mammal } & & & \multicolumn{2}{|c|}{ In Vitro } & \multicolumn{2}{|c|}{ In Vivo } & \multirow[b]{2}{*}{ Alert Ref ${ }^{a}$} & \multirow[b]{2}{*}{ Prediction } \\
\hline & Alert Ref ${ }^{a}$ & Prediction & Alert Ref ${ }^{a}$ & Prediction & Alert Ref ${ }^{a}$ & Prediction & Alert Ref ${ }^{a}$ & Prediction & Alert Ref $^{a}$ & Prediction & & \\
\hline AFB1 & 201 & PLAUSIBLE & 306 & PLAUSIBLE & 201 & EQUIVOCAL & 306,309 & PLAUSIBLE & $-b$ & $-b$ & 306 & PLAUSIBLE \\
\hline STER & 201 & PLAUSIBLE & 306 & PLAUSIBLE & 201 & EQUIVOCAL & 306 & PLAUSIBLE & $-b$ & $-b$ & 306 & PLAUSIBLE \\
\hline NIV & 019 & PLAUSIBLE & $-b$ & $-b$ & 019 & PLAUSIBLE & 019,309 & PLAUSIBLE & 019 & PLAUSIBLE & $-b$ & $-b$ \\
\hline $3 \mathrm{ADON}$ & 019 & PLAUSIBLE & $-b$ & $-b$ & 019 & PLAUSIBLE & 019,309 & PLAUSIBLE & 019 & PLAUSIBLE & $-b$ & $-b$ \\
\hline 15ADON & 019 & PLAUSIBLE & $-b$ & $-b$ & 019 & PLAUSIBLE & 019,309 & PLAUSIBLE & 019 & PLAUSIBLE & $-b$ & $-b$ \\
\hline $\mathrm{F}-\mathrm{X}$ & 019 & PLAUSIBLE & $-b$ & $-b$ & 019 & PLAUSIBLE & 019,309 & PLAUSIBLE & 019 & PLAUSIBLE & $-b$ & $-b$ \\
\hline $\mathrm{T}-2$ & 019 & PLAUSIBLE & $-b$ & $-b$ & 019 & PLAUSIBLE & 019 & PLAUSIBLE & 019 & PLAUSIBLE & $-b$ & $-b$ \\
\hline HT-2 & 019 & PLAUSIBLE & $-b$ & $-b$ & 019 & PLAUSIBLE & 019 & PLAUSIBLE & 019 & PLAUSIBLE & $-b$ & $-b$ \\
\hline OTA & $(*)^{c}$ & INACTIVE & $-b$ & $-b$ & $-b$ & $-b$ & $-b$ & $-b$ & $-b$ & $-b$ & $-b$ & $-b$ \\
\hline ZEA & $(*)^{\mathrm{c}}$ & INACTIVE & $-b$ & $-b$ & $-b$ & $-b$ & $-b$ & $-b$ & $-b$ & $-b$ & $-b$ & $-b$ \\
\hline FB1 & $(*)^{c}$ & INACTIVE & $-b$ & $-b$ & $-b$ & $-b$ & $-b$ & $-b$ & $-b$ & $-b$ & $-b$ & $-b$ \\
\hline
\end{tabular}

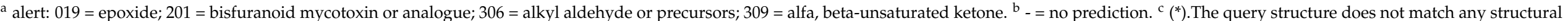

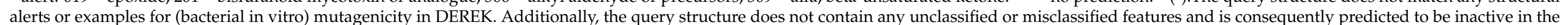
bacterial in vitro (Ames) mutagenicity test. ${ }^{\mathrm{d}}$ No predictions for any of the mycotoxins were obtained for non-specific genotoxicity in vivo. 
Table 3. VEGA QSAR@ mutagenicity outcomes for analyzed mycotoxins.

\begin{tabular}{|c|c|c|c|c|}
\hline Mycotoxin & VEGA Tool & $\operatorname{Exp}^{a}$ & Pdtion $^{b}$ & SA/SM ${ }^{c}$ \\
\hline \multirow[t]{4}{*}{ AFB1 } & CAESAR & M & M & - \\
\hline & SarPy/IRFMN & M & M & SM: 35, 141, 154, 158, 177, 187, 196 \\
\hline & ISS & M & M & SA:30 \\
\hline & KNN/Racross & M & M & \\
\hline \multirow[t]{4}{*}{ STER } & CAESAR & M & M & - \\
\hline & SarPy/IRFMN & M & M & SM: $35,59,84$ \\
\hline & ISS & M & M & SA:59 \\
\hline & KNN/Racross & - & M & \\
\hline \multirow[t]{4}{*}{ NIV } & CAESAR & NM & suspect M & SA:7 \\
\hline & SarPy/IRFMN & NM & M & SM: $92,97,113,162,163,169,177,182,186$ \\
\hline & ISS & - & M & SA: 7,10 \\
\hline & KNN/Racross & NM & NM & \\
\hline \multirow[t]{4}{*}{ DON } & CAESAR & NM & suspect M & SA: 7 \\
\hline & SarPy/IRFMN & NM & $\mathrm{M}$ & SM: 92, 97, 113, 162, 163, 169, 177, 182, 186 \\
\hline & ISS & - & M & SA: 7,10 \\
\hline & KNN/Racross & NM & NM & \\
\hline \multirow[t]{4}{*}{$3 \mathrm{ADON}$} & CAESAR & - & suspect M & SA: 7 \\
\hline & SarPy/IRFMN & - & $\mathrm{M}$ & SM: $92,97,113,162,163,169,177,182,186,188$ \\
\hline & ISS & - & M & SA: 7,10 \\
\hline & KNN/Racross & - & NM & \\
\hline \multirow[t]{4}{*}{$15 \mathrm{ADON}$} & CAESAR & - & suspect M & SA: 7 \\
\hline & SarPy/IRFMN & - & $\mathrm{M}$ & SM: $92,97,113,123,162,163,169,177,182,186,188$ \\
\hline & ISS & - & M & SA: 7,10 \\
\hline & KNN/Racross & - & NM & \\
\hline \multirow[t]{4}{*}{ F-X } & CAESAR & NM & suspect M & SA: 7 \\
\hline & SarPy/IRFMN & NM & $\mathrm{M}$ & SM: $92,97,113,162,163,169,177,182,186,188$ \\
\hline & ISS & - & M & SA: 7,10 \\
\hline & KNN/Racross & - & NM & \\
\hline \multirow[t]{4}{*}{$\mathrm{T}-2$} & CAESAR & NM & suspect M & SA: 7 \\
\hline & SarPy/IRFMN & NM & M & SM: $92,97,113,162,163,169,178,182,186,188$ \\
\hline & ISS & - & M & SA:7 \\
\hline & KNN/Racross & - & NM & \\
\hline \multirow[t]{4}{*}{ HT-2 } & CAESAR & - & suspect M & SA:7 \\
\hline & SarPy/IRFMN & - & $\mathrm{M}$ & SM: $92,97,113,123,162,163,169,178,182,186,188$ \\
\hline & ISS & - & M & SA:7 \\
\hline & KNN/Racross & - & NM & \\
\hline \multirow[t]{4}{*}{ OTA } & CAESAR & - & NM & - \\
\hline & SarPy/IRFMN & - & NM & SM: $146,170,189,190$ \\
\hline & ISS & NM & NM & - \\
\hline & KNN/Racross & NM & NM & \\
\hline \multirow[t]{4}{*}{ ZEA } & CAESAR & NM & NM & - \\
\hline & SarPy/IRFMN & NM & NM & SM: $146,163,170,177,189$ \\
\hline & ISS & NM & NM & - \\
\hline & KNN/Racross & NM & NM & \\
\hline \multirow[t]{4}{*}{ FB1 } & CAESAR & - & NM & - \\
\hline & SarPy/IRFMN & - & NM & SM: 121, 137, 157, 163, 169, 178, 182, 188 \\
\hline & ISS & NM & NM & - \\
\hline & KNN/Racross & NM & NM & \\
\hline
\end{tabular}

${ }^{\mathrm{a}}$ Exp = experimental data; ${ }^{\mathrm{b}}$ Pdtion = prediction, non-mutagenic $(\mathrm{NM})$, mutagenic $(\mathrm{M})$ and suspected to be mutagenic (suspect $\left.\mathrm{M}\right)$.

c SA: structural alert; SM: substructure (SMART) related with mutagenicity (1-112) or non- mutagenicity (number higher than 112); see

Supplementary Material for details. 
Table 4. VEGA QSAR@ prediction quality outcomes for each mycotoxin.

\begin{tabular}{|c|c|c|c|c|c|c|c|c|c|c|}
\hline \multirow{2}{*}{ Ref } & \multirow{2}{*}{ VEGA Tool } & \multicolumn{9}{|c|}{ Prediction Quality VEGA Models Outcomes $^{a}$} \\
\hline & & AD & ADI & Reliability & CONSENSUS & Sim & Acc & $\mathrm{Cc}$ & DRC & $\mathrm{ACF}$ \\
\hline \multirow[t]{4}{*}{ AFB1 } & CAESAR & INTO & 1 & good & $\mathrm{M}$ & 1 & 1 & 1 & True & 1 \\
\hline & SarPy/IRFMN & INTO & 1 & good & & 1 & 1 & 1 & & 1 \\
\hline & ISS & INTO & 1 & good & & 1 & 1 & 1 & & 1 \\
\hline & KNN/Racross & INTO & 1 & good & & 1 & 1 & 1 & & 1 \\
\hline \multirow{4}{*}{ STER } & CAESAR & INTO & 1 & good & M & 1 & 1 & 1 & True & 1 \\
\hline & SarPy/IRFMN & INTO & 1 & good & & 1 & 1 & 1 & & 1 \\
\hline & ISS & INTO & 1 & good & & 1 & 1 & 1 & & 1 \\
\hline & KNN/Racross & could out & 0.76 & moderate & & 0.963 & 0.49 & 0.75 & & 1 \\
\hline \multirow[t]{4}{*}{ NIV } & CAESAR & OUT & 0 & low & NM & 1 & 0 & 0 & True & 1 \\
\hline & SarPy/IRFMN & OUT & 0 & low & & 1 & 0 & 0 & & 1 \\
\hline & ISS & OUT & 0 & low & & 0.80 & 0.51 & 0.51 & & 1 \\
\hline & KNN/Racross & INTO & 1 & good & & 1 & 1 & 1 & & 1 \\
\hline \multirow[t]{4}{*}{ DON } & CAESAR & OUT & 0 & low & NM & 1 & 0 & 0 & True & 1 \\
\hline & SarPy/IRFMN & OUT & 0 & low & & 1 & 0 & 0 & & 1 \\
\hline & ISS & OUT & 0.64 & low & & 0.80 & 0.51 & 0.51 & & 1 \\
\hline & KNN/Racross & INTO & 1 & good & & 1 & 1 & 1 & & 1 \\
\hline \multirow[t]{4}{*}{$3 \mathrm{ADON}$} & CAESAR & OUT & 0 & low & NM & 0.96 & 0 & 0 & True & 1 \\
\hline & SarPy/IRFMN & OUT & 0 & low & & 0.96 & 0 & 0 & & 1 \\
\hline & ISS & OUT & 0.65 & low & & 0.82 & 0.51 & 0.51 & & 1 \\
\hline & KNN/Racross & INTO & 0.97 & good & & 0.94 & 1 & 1 & & 1 \\
\hline \multirow[t]{4}{*}{ 15ADON } & CAESAR & OUT & 0 & low & NM & 0.96 & 0 & 0 & True & 1 \\
\hline & SarPy/IRFMN & OUT & 0 & low & & 0.96 & 0 & 0 & & 1 \\
\hline & ISS & OUT & 0.64 & low & & 0.82 & 0.51 & 0.51 & & 1 \\
\hline & KNN/Racross & INTO & 0.97 & good & & 0.94 & 1 & 1 & & 1 \\
\hline \multirow[t]{4}{*}{ F-X } & CAESAR & OUT & 0 & low & NM & 1 & 0 & 0 & True & 1 \\
\hline & SarPy/IRFMN & OUT & 0 & low & & 1 & 0 & 0 & & 1 \\
\hline & ISS & could out & 0.90 & moderate & & 1 & 1 & 1 & & 1 \\
\hline & KNN/Racross & INTO & 0.97 & good & & 0.93 & 1 & 1 & & 1 \\
\hline \multirow[t]{4}{*}{$\mathrm{T}-2$} & CAESAR & OUT & 0 & low & NM & 1 & 0 & 0 & True & 1 \\
\hline & SarPy/IRFMN & OUT & 0 & low & & 1 & 0 & 0 & & 1 \\
\hline & ISS & could out & 0.86 & moderate & & 0.78 & 1 & 1 & & 1 \\
\hline & KNN/Racross & could out & 0.78 & moderate & & 0.854 & 1 & 0.52 & & 1 \\
\hline \multirow[t]{4}{*}{ HT-2 } & CAESAR & OUT & 0 & low & M & 0.935 & 0 & 0 & True & 1 \\
\hline & SarPy/IRFMN & OUT & 0 & low & & 0.935 & 0 & 0 & & 1 \\
\hline & ISS & could out & 0.89 & moderate & & 0.8 & 1 & 1 & & 1 \\
\hline & KNN/Racross & could out & 0.87 & moderate & & 0.877 & 1 & 0.75 & & 1 \\
\hline \multirow[t]{4}{*}{ OTA } & CAESAR & could out & 0.72 & moderate & NM & 0.83 & 1 & 0.38 & True & 1 \\
\hline & SarPy/IRFMN & could out & 0.72 & moderate & & 0.83 & 1 & 0.38 & & 1 \\
\hline & ISS & INTO & 1 & good & & 1 & 1 & 1 & & 1 \\
\hline & KNN/Racross & INTO & 1 & good & & 1 & 1 & 1 & & 1 \\
\hline \multirow[t]{4}{*}{ ZEA } & CAESAR & INTO & 1 & good & NM & 1 & 1 & 1 & True & 1 \\
\hline & SarPy/IRFMN & INTO & 1 & good & & 1 & 1 & 1 & & 1 \\
\hline & ISS & INTO & 1 & good & & 1 & 1 & 1 & & 1 \\
\hline & KNN/Racross & INTO & 1 & good & & 1 & 1 & 1 & & 1 \\
\hline \multirow[t]{4}{*}{ FB1 } & CAESAR & could out & 0.88 & moderate & NM & 0.908 & 1 & 0.71 & True & 1 \\
\hline & SarPy/IRFMN & could out & 0.80 & moderate & & 0.908 & 0.71 & 0.71 & & 1 \\
\hline & ISS & INTO & 1 & good & & 1 & 1 & 1 & & 1 \\
\hline & KNN/Racross & INTO & 1 & good & & 1 & 1 & 1 & & 1 \\
\hline
\end{tabular}

a AD: applicability of domain; ADI: applicability of domain index; Sim: similarity; Acc: accuracy; Cc: concordance; DRC: descriptors range check; ACF: atom-centred fragments; NM: non-mutagenic; M: mutagenic; suspect M: suspected to be mutagenic. Soft grey: no optimal assessment; numbers in bold and strong grey: bad assessment. Results are expressed in a quantitative way (0 to 1 ), except for AD (into, out, could out) and for DRC (true, false). Reliability of the prediction, based on the overall results obtained, is expressed as good, low or moderate.

According to the SarPy/IRFMN approach, AFB1 shows a 2-vinyloxyethylbenzene fragment which implies a structural alert (SM35) for mutagenicity. Moreover, some nonmutagenicity alerts are detected: SM141, SM154, SM158, SM177, SM187 and SM196 (see Table S3 for details).

According to the ISS approach, this compound shows a coumarin moiety (SA30) related to mutagenicity (Table S4). 
With respect to STER, the experimental outputs from three models (CAESAR, SarPy/IRFMN and ISS) agreed on its mutagenic potential. SarPy/IRFFMN detected, in addition to the SM35 alert that is common with AFB1, the presence of (2-hydroxyphenyl)-phenylmethanone (SM59) and 9H-xanthen-3-ol (SA84) moieties, which implies mutagenicity. Meanwhile ISS detected the presence of a fragment related to the structure of demonstrated DNA intercalating agents (SA59, xanthones, thioxanthones, acridones). The prediction outputs from these models were also positive with good reliability (Table 4).

Based on the abovementioned results, the consensus obtained with VEGA QSAR@ was mutagenicity for both mycotoxins (Table 4).

Therefore, regarding Phase I, the overall classification for AFB1 and STER could be "mutagenic" based on outputs from both in silico tools.

\subsubsection{Group 2 (Trichothecenes: NIV, DON, 3ADON, $15 \mathrm{ADON}, \mathrm{F}-\mathrm{X}, \mathrm{T}-2$ and HT-2 Toxins)}

The prediction from DEREK Nexus ${ }^{\circledR}$ for these compounds detects the presence of the epoxide (Alert 019) that decorates the common scaffold. Therefore, a plausible mutagenicity and chromosomal damage was predicted in vitro and in vivo.

In addition, NIV, DON, 3DON, 15ADON and F-X showed an $\alpha, \beta$-unsaturated ketone (Alert 309) toxophore, also present in AFB1, which reinforces the plausibility of a genotoxic potential in vitro and in vivo (see Table 2). Therefore, there was a positive genotoxic potential of the mycotoxins from this group, after screening phase 1 with DEREK Nexus ${ }^{\circledR}$.

Considering VEGA QSAR@ outcomes, the CAESAR approach detected the presence of the epoxide (SA7) (Table S2) in all compounds belonging to this group, and therefore labelled them as suspects of mutagenicity. With respect to the SarPy/IRFMN model, it detected two common SM alerts, related to the presence of oxiran-2-ylmethanol (SA92) and epoxide (SA97) moieties. These alerts are accompanied by a series of non-mutagenicity ones (see Tables 3 and S3). The ISS approach also detected epoxide (SA7) in all the analyzed structures, as well as alpha, beta unsaturated carbonyls (SA10), except for T-2 and HT-2 (Table S4).

According to the aforementioned data, some structural alerts have been detected for this group of mycotoxins and the predictions labelled the mycotoxins as "mutagenic" in 3 of the 4 models used (CAESAR, SarPy/IRFMN and ISS). Unfortunately, the quality obtained for these predictions (Table 4) was low, as all the mycotoxins were "out" or "almost

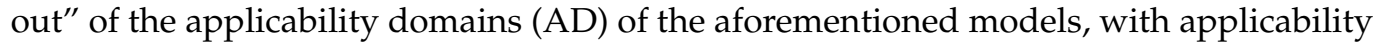
domain indexes (ADI) of 0 in many cases. The AD of a model is the physico-chemical, structural or biological space, knowledge or information on which the training set of the model has been developed, and for which it is applicable to make predictions for new compounds. It is a calculated region of the chemical space of the training dataset used to make the model [65]. Moreover, there was no concordance between the prediction and experimental outputs retrieved for NIV, DON and F-X. For instance, NIV and DON showed no mutagenicity from experimental outputs of three models (CAESAR, SarPy/IRFMN and KNN/Read-across while F-X obtained negative experimental outputs from two models (CAESAR and SarPy/IRFMN). The highest reliability prediction (ADI = 1) was provided by KNN/Racross model for NIV, DON, 3ADON, 15ADON and F-X. The prediction of this model matched with the experimental outputs as well with the final consensus outcome from VEGA QSAR@: non- mutagenic (see Table 4).

Regarding T-2 and HT-2, the predictions were also considered to be of low quality, as both mycotoxins were "out" or "almost out" in the AD of the four models. Moreover, T-2 experimental outputs from two models (CAESAR and SarPy/IRFMN) indicated an absence of mutagenicity, whereas HT-2 did not have experimental outputs in any model. Despite having similar prediction patterns, the absence of experimental outputs for the HT-2 toxin induced contradictory conclusions in the consensus outcomes from VEGA QSAR@: the T-2 toxin was considered not mutagenic, while HT-2 was labelled mutagenic.

Overall, for this group of mycotoxins, DEREK ${ }^{\circledR}$ labelled them as mutagenic while the consensus analysis retrieved from VEGA QSAR@ labelled them as non-mutagenic, except 
in the case of HT-2. Therefore, considering Phase I the overall classification for this group of mycotoxins, could be "equivocal" based on the outputs obtained in both in silico tools.

\subsubsection{Group 3 (OTA, FB1 and ZEA)}

The overlap predictions among OTA, ZEA and FB1 from screening phase 1, agreed on the absence of structural alert activation in any genotoxicity endpoint. With DEREK Nexus ${ }^{\circledR}$, there was just a specific label of no effect for in vitro mutagenicity in bacteria (Table 2). Therefore, the conclusion in this group is a negative genotoxicity potential in all cases.

In relation to the outcomes obtained with VEGA QSAR@ for OTA, ZEA and FB1, two models (ISS and KNN/Read-across) gave a sufficiently reliable (ADI $=1$ ) negative prediction (Table 4). The experimental outputs showed non-mutagenic activity in the same two models for OTA and FB1. In the case of ZEA, all experimental outputs from the four models agreed on negative mutagenicity. Indeed, the consensus retrieved from VEGA QSAR@ was absence of mutagenicity for the three mycotoxins (Table 4).

Therefore, the overall classification from Phase 1 for OTA, ZEA and FB1 was "nonmutagenic".

\subsection{In Vitro Genotoxicity Screening (Phase 2): SOS/umu Test}

2.3.1. Exposure Concentrations and Solubility

The maximal concentration to be tested in the SOS/umu test is $1000 \mu \mathrm{g} / \mathrm{mL}$ per well. To this aim, stock solutions at $40 \mathrm{mg} / \mathrm{mL}$ in dimethyl sulfoxide (DMSO) (water for FB1) were prepared except for AFB1 $(5 \mathrm{mg} / \mathrm{mL})$, STER $(5.88 \mathrm{mg} / \mathrm{mL}), \mathrm{DON}(35 \mathrm{mg} / \mathrm{mL})$ and ZEA $(37 \mathrm{mg} / \mathrm{mL})$, which were insoluble at higher concentrations.

In the case of NIV, 3ADON, $15 \mathrm{ADON}$ and the HT-2 toxin, as they were highly soluble and non-toxic for bacteria at the maximal concentration of $40 \mathrm{mg} / \mathrm{mL}$, two higher concentrations of 160 and $80 \mathrm{mg} / \mathrm{mL}$ (corresponding to 4000 and $2000 \mu \mathrm{g} / \mathrm{mL}$, respectively, in the well-plate) were also included in an independent experiment.

Some mycotoxins precipitated during the SOS/umu test. The concentrations containing precipitates were not considered for analysis.

\subsubsection{SOS/Umu Test}

Screening phase 2 corresponded to the SOS/umu test. From the eleven concentrations tested for each mycotoxin, the wells containing precipitates of the mycotoxin were not considered for analysis (and thus are not shown in Figures 5-8). Mycotoxins were considered genotoxic if the induction factor (IF) was higher than 2 at non-toxic concentrations (bacterial survival higher than $80 \%$ ) at any of the concentrations tested without or with metabolic activation. In all the experiments, all the controls used were correct (IF $<2$ for negative and $>2$ for positive controls).

\subsubsection{Group 1 (AFB1 and STER)}

AFB1 showed a positive genotoxic concentration response in both without (PBS) and with metabolic activation (S9), but with a much greater response with metabolic activation (positive from $0.24 \mu \mathrm{g} / \mathrm{mL}$ ). The three highest concentrations tested $(31.25-125 \mu \mathrm{g} / \mathrm{mL}$ ) with the metabolic activation were toxic for the bacteria. STER precipitated at the highest concentrations (from 9.2 to $147 \mu \mathrm{g} / \mathrm{mL}$ ) and was very toxic to the bacteria (from $0.57 \mu \mathrm{g} / \mathrm{mL}$ ) with metabolic activation (data not shown), and thus lower concentrations were tested (Figure 5). STER was not genotoxic without metabolic activation but showed genotoxicity with metabolic activation (IF $>2$ from $0.14 \mu \mathrm{g} / \mathrm{mL}$ ). 


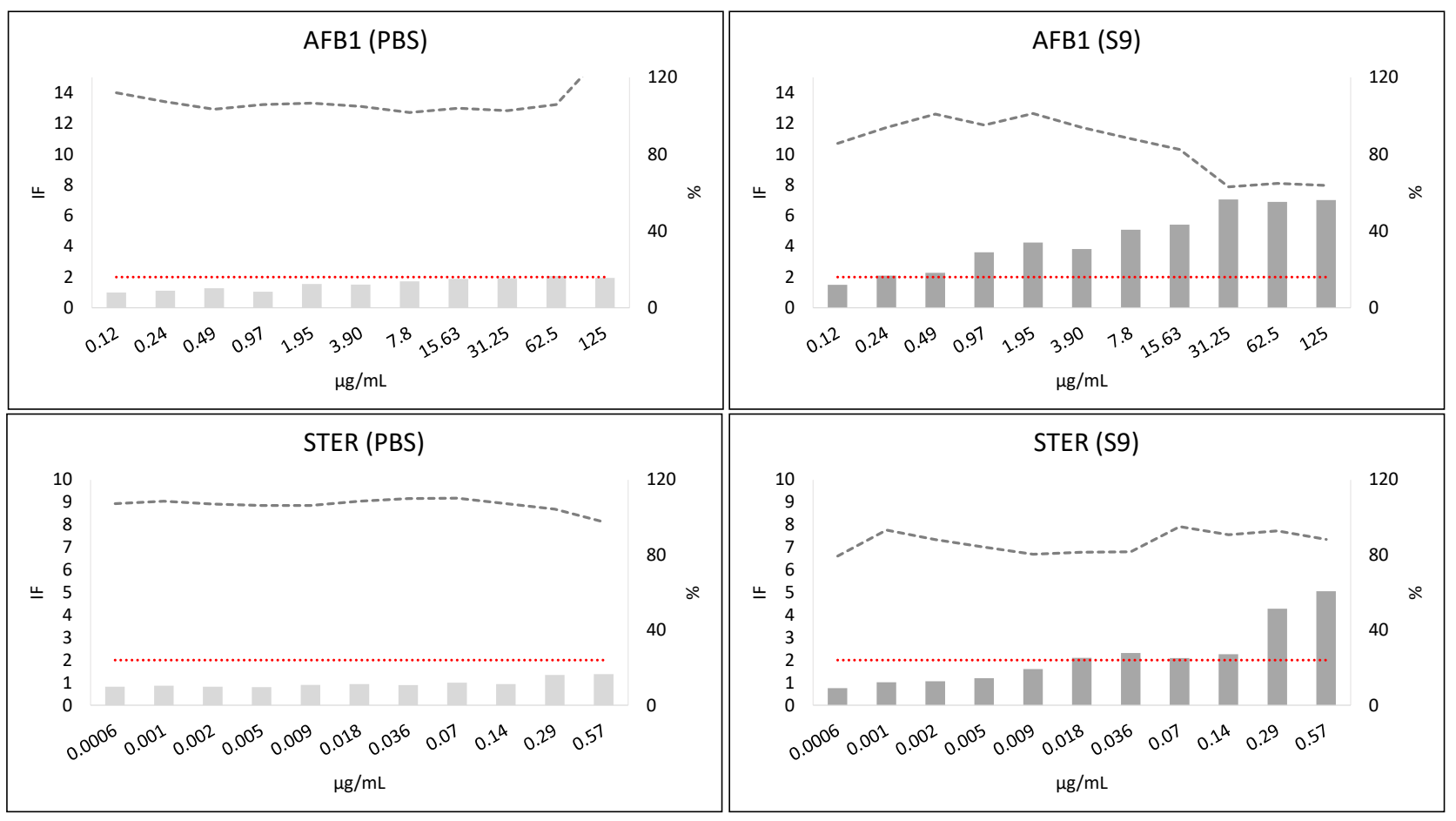

$$
\square \text { PBS L Liver S9 } \quad----\% \text { survival } \quad \text {........ IF }=2
$$

Figure 5. Results from SOS/umu test with (dark grey) or without S9 (light grey) activation for AFB1 and STER. Bacterial survival is shown as percentage (\%). Concentrations are considered non-toxic if survival is $>80 \%$. A compound is considered genotoxic if the induction factor (IF) is $\geq 2$ at non-toxic concentrations for the bacteria in any of the conditions tested.

\subsubsection{Group 2 (NIV, DON, 3ADON, $15 \mathrm{ADON}, \mathrm{F}-\mathrm{X}, \mathrm{T}-2$ and HT-2 Toxins)}

All the mycotoxins showed IF lower than 2 in the absence (PBS) and presence of metabolic activation (S9). However, NIV, 3ADON, 15ADON, T-2 and HT-2 toxin showed some results IF $\geq 1.5$. Taking into account these results, as well the Phase I outcome, they were considered as equivocal. Moreover, they were very soluble and non-toxic for bacteria. Therefore, a second experiment at higher concentrations (maximal concentration $4000 \mu \mathrm{g} / \mathrm{mL}$ ) was carried out. The mycotoxin T-2 precipitated at 1000, 2000 and $4000 \mu \mathrm{g} / \mathrm{mL}$. The rest of the mycotoxins did not show precipitates at any of the concentrations. This second experiment showed IF below 1.5 in all cases (Figure S1) and allowed us to consider these mycotoxins as "non-mutagenic".

\subsubsection{Group 3 (OTA, FB1 and ZEA)}

OTA, ZEA and FB1 showed a clear negative genotoxic response in the absence (PBS) or presence of metabolic activation (S9). In all cases IF was well below 2.

Overall, taking into account the results from the SOS/umu test, AFB1 and STER could be considered clearly genotoxic, while DON, F-X, OTA, ZEA and FB1 were clearly non-genotoxic. Some equivocal results were obtained with NIV, 3-ADON, 15-ADON and $\mathrm{T}-2 / \mathrm{HT}-2$ toxins but were confirmed as negative in a second experiment. 


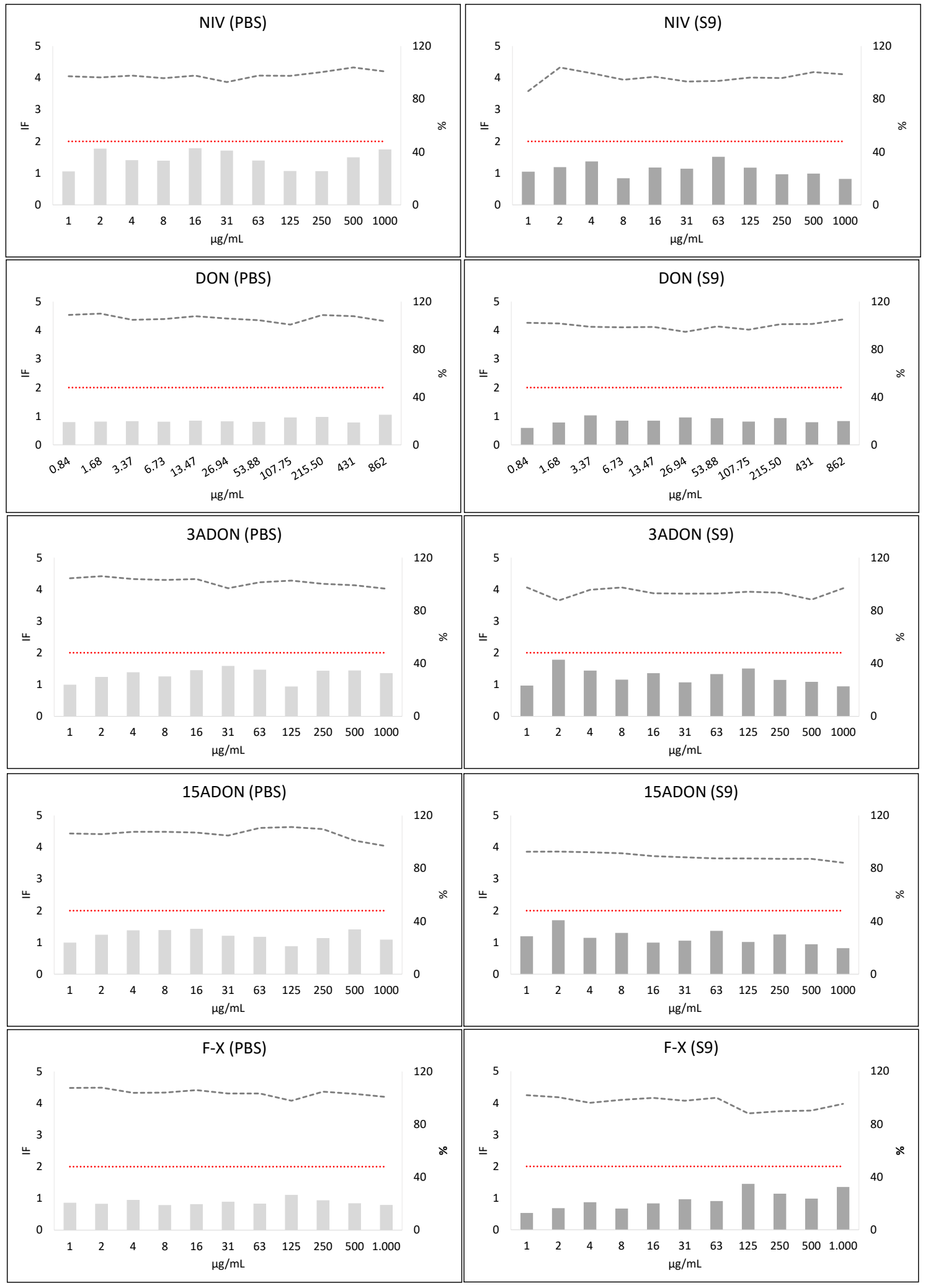

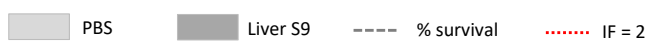

Figure 6. Results of SOS/umu test with (dark grey) or without S9 (light grey) activation for NIV, DON, 3ADON, 15ADON and F-X. Bacterial survival is shown as percentage (\%). Concentrations are considered non-toxic if survival is $>80 \%$. A compound is considered genotoxic if the induction factor (IF) is $\geq 2$ at non-toxic concentrations for the bacteria in any of the conditions tested. 


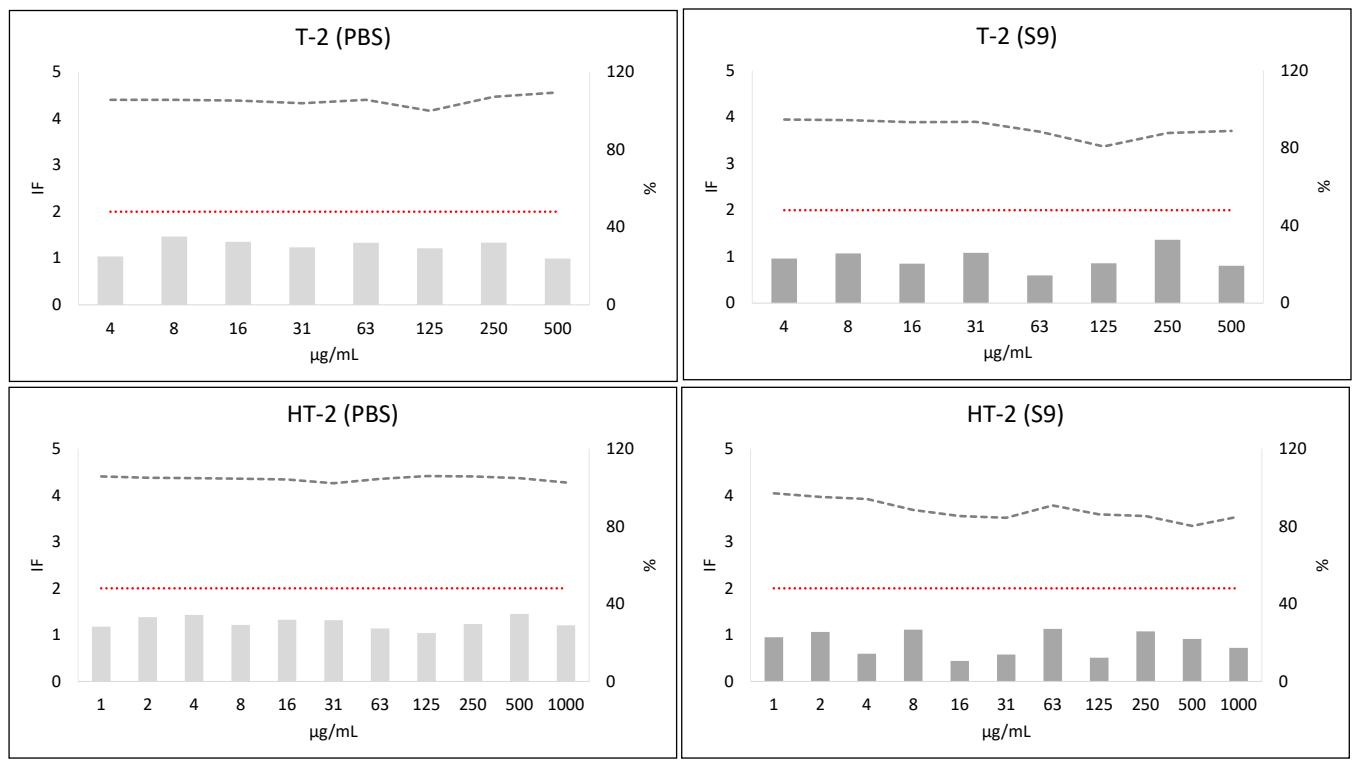

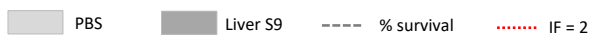

Figure 7. Results from SOS/umu test with (dark grey) or without S9 (light grey) activation for T-2 and HT-2. Bacterial survival is shown as percentage (\%). Concentrations are considered non-toxic if survival is $>80 \%$. A compound is considered genotoxic if the induction factor (IF) is $\geq 2$ at non-toxic concentrations for the bacteria in any of the conditions tested.

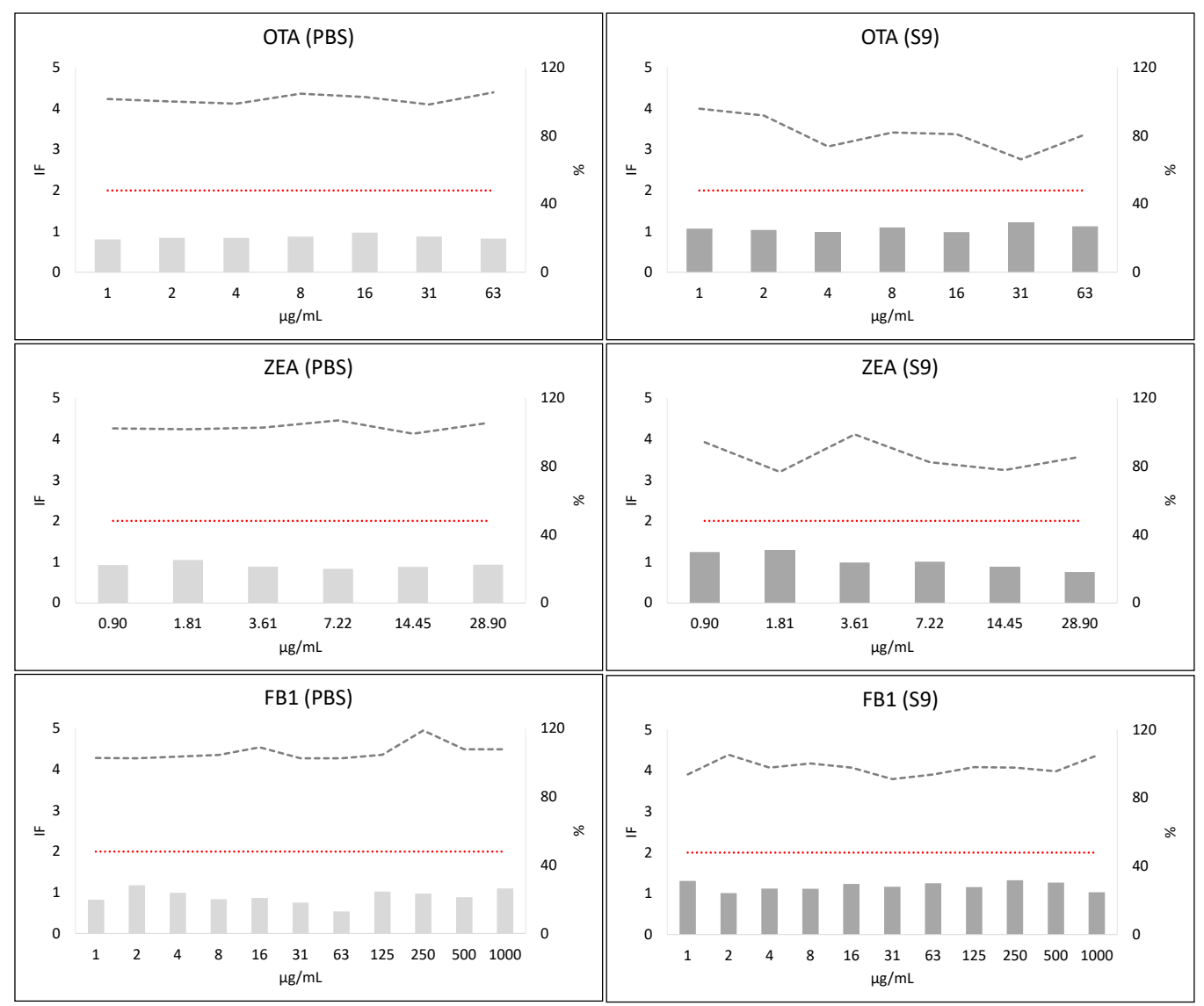

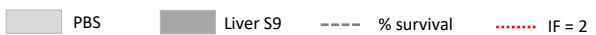

Figure 8. Results from SOS/umu test with (dark grey) or without S9 (light grey) activation for OTA, ZEA and FB1. Bacterial survival is shown as percentage (\%). Concentrations are considered non-toxic if survival is $>80 \%$. A compound is considered genotoxic if the induction factor (IF) is $\geq 2$ at non-toxic concentrations for the bacteria in any of the conditions tested. 


\section{Discussion}

The identification and initial toxicological characterization of emerging risks is at the heart of public health protection [66]. The current climate change scenario might also affect human exposure to mycotoxins as it is known that changes in temperature, humidity, rainfall and carbon dioxide production impact on fungal behavior and consequently on mycotoxin production. Moreover, it is known that animals and humans are not only exposed to one single mycotoxin, but to cocktails of different contaminants. On the other hand, the current paradigm shift from traditional toxicology testing (in vivo) towards alternative methods following the $3 \mathrm{R}$ principles (replacement, reduction and refinement of animal testing) brings forth the use of in silico and in vitro methods. The current genotoxicity testing battery used for pharmaceuticals [58] and for food safety assessment [59] is a stepwise battery that begins with in vitro tests, generally an Ames test [60] and micronucleus tests [61], followed by an in vivo test if needed. The genotoxic endpoint assessed in this battery are mainly point mutations (Ames test) and chromosome aberrations (micronucleus assay). However, the in vitro part of this battery might be time-consuming (from 2-3 weeks per complete assay) and high amounts of test items are generally needed. The substance availability is indeed a usual problem for mycotoxin evaluation as many of them are very expensive or not commercially available. Thus, there is a need to develop tiered approaches for prioritizing mycotoxins or mixtures that need to be further studied.

It is known that in silico methods are not yet ready for fully replacing in vitro and in vivo testing. For this reason, the ICH M7 [57] strategy reccomends the use of two in silico methods (expert knowledge-based and statistical-based) for genotoxicity prediction of pharmaceutical impurities. Morever, it has also been demonstrated that the combination of methods increases the performance of the models used for genotoxicity prediction of food contact material, although this was more relevant for QSAR methods [67].

Therefore, two different already available in silico tools were used in the present study.

DEREK Nexus ${ }^{\circledR}$ is commercial, based on expert knowledge and it is normally used by pharmaceutical companies as a part of an ICH M7 workflow to detect mutagenic impurities. In our case, only OTA, ZEA and FB1 were considered inactive for mutagenicity in vitro, with no prediction for the rest of genotoxiticity endpoints. The rest of the mycotoxins showed structural alerts for mutagenicity and chromosome damage, however with a lower level of evidence within the positive range (that goes from plausible to certain), as they were labeled as "plausible". Therefore, DEREK allowed us to clearly group the mycotoxins into two clusters: negative for gene mutation (OTA, ZEA and FB1) or mycotoxins with some alerts for genotoxicity.

VEGA QSAR@ is free, statistical-based and includes several models for mutagenicity prediction (CAESAR, SarPy/IRFMN, ISS, KNN/Racross), as well as an independent algorithm to assess the reliability of the model predictions through the ADI. The ADI algorithm works on all the separate models and shows similar compounds, assesses the statisticalbased results on the similar compounds, and analyses some relevant chemical features in the target compound and its related compounds. Thereafter, an automatic evaluation for read-across is completed, and thus this tool can be used for read-across, independently from the prediction obtained through the models. Moreover, VEGA consensus was also used as previous studies have demonstrated that when the performance varies among the different mutagenicity models used, it increased the prediction performance. The weighted consensus read-accross result is obtained by taking into account the result of each of the models and their associated compound-specific ADI [67]. In our case, very good predictions were obtained for AFB1 (mutagenic) and ZEA (non-mutagenic), with ADI of 1 in all the models used. Some of the other mycotoxins were also predicted with good quality $(\mathrm{ADI}=1)$ in some of the models, such as STER (mutagenic) in CAESAR, SarPy/IRFMN and ISS; NIV and DON (both labelled as non-mutagenic) in KNN/read-across; and OTA and FB1 (non-mutagenic) in ISS and KNN/read-across. In the case of STER, OTA and FB1, the rest of the models gave moderate predictions (ADI between 0.72 and 0.82), but in all cases, the prediction matched the results obtained with the models showing higher ADI, as 
well the experimental data included in the different databases. Moreover, ADI levels higher than 0.75 have been considered to be of enough quality for genotoxicity prediction [67]. Thus, it can be considered that there is enough evidence to classify STER as mutagenic, while OTA and FB1 can be labelled as non-mutagenic. However, the level of evidence to classify the rest of mycotoxins was much lower. Indeed all the group 2 of structurally related mycotoxins (trichothecenes: NIV, DON, 3ADON, 15ADON,1 F-X, T-2 and HT-2) were totally out of the domain of two of the models (CAESAR and SarPy/IRFMN) that indeed classified these molecules as mutagenic or suspected to be mutagenic. ISS, a model that showed a low or moderate quality prediction (ADI below 0.75 for NIV, DON, 3ADON and $15 \mathrm{ADON}$, and ADI higher than 0.75 for F-X, T-2 and HT-2), and also classified them as mutagenic. The model showing higher levels of quality predictions for this group of mycotoxins was KNN/Racross with ADI between 0.78 and 1; however, it classified them as non-mutagenic. The KNN/Racross classification was in concordance with the experimental data retrieved for these mycotoxins in the databases of some of the models, except for $3 \mathrm{ADON}, 15 \mathrm{ADON}$ and HT-2 for which experimental data were lacking. Thus, based on the results obtained with the in silico tools, we considered these mycotoxins as equivocal for mutagenicity.

One important aspect to point out is that in silico tools for mutagenicity prediction are mainly built based on in vitro experimental data, mainly from the Ames test [68-72], and thus this should be taken into account when interpreting the classification "mutagenic" or " non-mutagenic" as the prediction is mainly focused on point mutation, but not for other genotoxic endpoints.

Therefore, in order to validate the in silico Phase 1, the SOS/umu test, an in vitro test with a high concordance with the Ames test was used [64]. Indeed, a comparison of this assay with other SOS Chromotests and the Ames test itself revealed that the sensitivity of the SOS/umu test was close to those of the Ames test strain TA98, both with and without metabolic activation. Moreover, the authors considered that this assay was especially suitable for screening complex environmental samples as it demonstrated a significant reduction in material expenses and workload compared to the Ames test [73].

The results obtained with the SOS/umu test confirmed the mutagenicity of AFB1 and STER (Group 1 of mycotoxins). This test added some extra information not obtained in Phase 1, regarding the need for metabolic activation, as both mycotoxins were only mutagenic when the S9 mix was used. The assay also confirmed the lack of mutagenicity of mycotoxins from Group 3 (OTA, ZEA and FB1), as the IF were always below the threshold for genotoxicity $(\mathrm{IF}<2)$. Indeed, the IF were always lower than 1.5 at all the concentrations tested with and without metabolic activation. Regarding Group 2, IF $<2$ were obtained for all the mycotoxins. However, values around or higher than 1.5 were reached. Therefore, a second experiment with higher concentrations was carried out with the mycotoxins that were soluble and non-toxic to the bacteria (NIV, 3ADON, 15ADON and T-2/HT-2 toxins). They were confirmed as "non-mutagenic".

The classification of the mycotoxins following the proposed strategy is in agreement with the published literature as well, with most risk assessments carried out by different international organizations.

The well-known AFB1, produced by the Aspergillus species, has been consistently found to be genotoxic and is considered a human carcinogen via DNA adduct formation after bioactivation $[8,74,75]$. STER, which is a precursor/intermediate of the aflatoxin (acetate-malonate) synthesis pathway, contaminates food and feed commodities but has not been fully characterized. Some studies confirmed the STER genotoxic potential, but the mode of action has not been clearly elucidated [76-78]. Both mycotoxins have been consistently found to be positive with Ames and SOS tests (see Table 1).

Another mycotoxin produced by the Aspergillus species is ochratoxin A (OTA). It is considered a potent nephrocarcinogen in rodents [14], although its mode of action is still unknown and a matter of debate [79]. The majority of the Ames and SOS tests carried out to date are negative, except for one study in which mice kidney microsomal fraction 
was used as metabolic activation [50]. In one SOS Chromotest, [33] OTA showed a slight increase in $\mathrm{SOS}$ response but with no dose effect.

The other mycotoxins selected to be evaluated with the proposed strategy are produced by Fusarium: zearalenone (ZEA), fumonisins and trichothecenes (types A and B and modified forms). Trichothecenes are structurally related toxins divided in four classes, with different chemical structures, biological effects and toxigenic fungi [80]. Types A and B have in common that they have an oxygen function at $\mathrm{C}-3$ and are produced by the same biosynthetic route [81]. T-2 and HT-2 are type A trichothecenes. T-2 has been assessed through Ames and SOS tests, and in both cases seems to be negative. However, no data for HT-2 have been found (see Table 1). These findings are in line with our negative SOS/umu results and with the most recent European Food Safety Authority (EFSA) evaluation in which it is clearly stated that the T-2 toxin has been shown to be negative in bacterial mutation assays [82]. However, it should be noted that several studies highlighted that $\mathrm{T}-2$ induces chromosomal damage in vitro and in vivo. However, it is not clear yet if the observed effects are a consequence of interaction of T-2 toxin with genetic material or are secondary to inhibition of protein synthesis or cytotoxicity [82]. Our in silico results have highlighted structural alerts related to epoxides, structures known to interact with DNA, in both in silico tools. Indeed, DEREK predicted plausible chromosome damage in vitro and in vivo for both mycotoxins. For VEGA QSAR $\odot$, it should be noted that the predictions were not of high enough quality.

Regarding the genotoxic potential of type B trichothecenes, the published literature indicates that it is inconclusive or unknown [10,83]. Our bibliographic search retrieved information indicating that DON, $3 \mathrm{ADON}$ and F-X were negative when tested with Ames and/or SOS tests. No data of the mutagenic potential of NIV and 15ADON has been retrieved from our systematic search (see Table 1). In the last EFSA evaluation [10], the panel concluded in agreement with our results from the SOS/umu test that DON is not mutagenic in bacteria or mammalian cells but considered that it causes chromosomal effects and DNA damage assessed by the comet assay in vitro, and that the effect was related to oxidative stress. Several in vivo studies carried out with DON gave inconclusive results [10]. Regarding the acetylated forms, very few studies have been carried out; however, they point to negative mutagenic effects in bacteria but again, some chromosomal aberrations have been observed in vitro for $3 \mathrm{ADON}$. No in vivo data were available for the acetylated forms [10]. In the case of NIV, negative results have been found in assays detecting point mutations [84]. Some positive genotoxic results have been observed in other assays, in vitro or in vivo, but the most recent evaluation from EFSA considered that the overall weight of evidence is that nivalenol is unlikely to be genotoxic [84]. Very few data points regarding F-X have been found. The only Ames test carried out (Table 1) agrees with our SOS/umu results.

Finally, regarding ZEA, it is considered a xenoestrogen, due to structural similarities with these natural components [85]. Again, ZEA showed negative results in bacterial gene mutation assays; however, it has been considered as a clastogenic compound [9]. Our strategy allowed us to detect a negative response for bacterial mutagenicity with DEREK and SOS/umu and was classified as non-mutagenic in the consensus from VEGA. However, there were no predictions for chromosomal damage in DEREK or lack of mutagenicity alerts in VEGA.

Among fumonisins, fumonisin B1 (FB1) is the most prevalent and most toxic derivative [86]. This mycotoxin is also considered non-mutagenic in bacterial assays (Table 1) [87], and thus our strategy was able to correctly classify it as non-mutagenic. However, as in the case of ZEA, we were not able to predict or to highlight alerts regarding other type of genotoxic endpoints; FB1 gave positive results for chromosomal damage and DNA breaks [87]. 


\section{Conclusions}

A strategy combining two in silico tools, i) the commercial tool DEREK Nexus ${ }^{\circledR}$ and ii) the publicly available VEGA QSAR $\odot$, followed by the in vitro SOS/umu test, allowed us to classify in a time- and cost-effective manner 12 mycotoxins based on their mutagenic potential (mutagenic, non-mutagenic, equivocal). The outputs correlated very well with the results obtained in the literature for the Ames test, which detects point mutations. The strategy does not allow the classification of mycotoxins based on their genotoxicity at the chromosome level; however, some alerts related to this endpoint could be also identified. To this aim, more data need to be included in the in silico models and a medium/high throughput assay for chromosome aberrations is needed.

Phase 1 (in silico) of the strategy revealed that some well-studied mycotoxins (trichothecenes) are out of the domain of applicability of the models. Thus, it is important to carefully check if the proposed strategy, or at least Phase 1, might be valid for emerging or modified mycotoxins. This first phase also allowed us to identify experimental data gaps for some mycotoxins (trichothecenes).

Regarding Phase 2 (in vitro), the SOS/umu test appeared as a very good screening test for the detection of the mutagenic potential of mycotoxins, as the obtained results correlated with the published Ames test results and the relatively old studies carried out with SOS tests. This test can be used independently of Phase 1 .

The combination of the in silico (Phase 1) and in vitro (Phase 2) methods allowed us to obtain more complete information for decision making in the prioritization process.

Overall, these kinds of strategies could be useful for the prioritization of emerging/modified mycotoxins and their mixtures, in order to select the ones that need to be first evaluated for genotoxicity.

\section{Materials and Methods}

\subsection{Chemicals and Reagents}

The chemical reagents and solvents used for the SOS/umu test were obtained from different commercial companies. DMSO and $\mathrm{Na}_{2} \mathrm{CO}_{3}$ were purchased from PanReac AppliChem (Barcelona, Spain). Bactotryptone for TGA medium was obtained from Bectone Dickinson (Madrid, Spain), dextrose and $\mathrm{NaCl}$ from PanReac AppliChem (Barcelona, Spain). Ampicillin, ONPG (2-nitrophenyl- $\beta$-D-galactopyranoside), the B-buffer ingredients $\left(\mathrm{Na}_{2} \mathrm{HPO}_{4}\right.$ $2 \mathrm{H}_{2} \mathrm{O}, \mathrm{NaH}_{2} \mathrm{PO}_{4} \mathrm{H}_{2} \mathrm{O}, \mathrm{MgSO}_{4} 7 \mathrm{H}_{2} \mathrm{O}$, sodium dodecyl sulfate, $\beta$-mercaptoethanol) in which the ONPG was dissolved and the positive controls 2-aminoanthracene (2AA) and 4nitroquinoline-N-oxide (4NQO) were purchased from Sigma-Aldrich (Darmstadt, Germany). The B-buffer also comprises $\mathrm{KCl}$, which was purchased from PanReac AppliChem (Barcelona, Spain). In this assay, a liver fraction (S9 fraction) from Sprague Dawley male rats of 6-8 weeks of age induced with Arocolor 1254 was purchased from Trinova Biochem (Giessen, Germany). The S9 mix (8\%) was prepared with phosphate buffer $\left(\mathrm{NaH}_{2} \mathrm{PO}_{4}\right.$ $\mathrm{H}_{2} \mathrm{O}, \mathrm{Na}_{2} \mathrm{HPO}_{4} 2 \mathrm{H}_{2} \mathrm{O}$ ), glucose-6-phosphate and NADP solutions, of which compounds were obtained from Sigma-Aldrich (Darmstadt, Germany) and saline solution ingredients $\left(\mathrm{MgCl}_{2} 6 \mathrm{H}_{2} \mathrm{O}, \mathrm{KCl}\right)$ from PanReac AppliChem (Barcelona, Spain). Afterwards, the S9 mix was filtered through a $0.45 \mu$ filter. Genetically modified Salmonella typhimurium 1535/pSK1002 was purchased from the German Collection for microorganisms and Cell cultures (DSMZ 9274) (Berlin, Germany) and used as SOS/umu test strain. The bacteria contain a plasmid in which two genes are fused, one involved in DNA repair and the other accountable for $\beta$-galactosidase activity [88]. Therefore, SOS repair activity is monitored through $\beta$-galactosidase induction activity determined with spectrophotometric measures. All mycotoxins were purchased from Sigma Aldrich (Darmstadt, Germany) in powder dissolved in DMSO or water and maintained at $-20^{\circ} \mathrm{C}$ until use. The reference commercial number and CAS number is indicated in each case: OTA (O1877; CAS: 303-47-9), ZEA (Z2125; CAS: 17924-92-4), FB1 (F1147; CAS: 116355-83-0), DON (D0156; CAS: 51481-10-8), F-X (33438; CAS:23255-69-8), AFB1 (A6636; CAS: 1162-65-8), STER (S3255; CAS:10048-13-2), NIV (32929; CAS: 23282-20-4), 3ADON (A6166; CAS:50722-38-8), 15ADON (32928; CAS: 
88337-96-6), T-2 toxin (33947; CAS: 21259-20-1), and HT-2 toxin (T4138; CAS: 26934-872). The solutions were prepared in a chemical cabinet [89]. During the procedure, the manipulator wore a protective mask filter face piece type 3 (FFP3) and double gloves.

\subsection{In Silico Toxicology (Phase 1)}

\subsubsection{DEREK Nexus ${ }^{\circledR}$}

The expert knowledge rule-based software employed was Derek Nexus ${ }^{\circledR}$ (v 6.0.1, Lhasa Limited, Leeds, UK,) [90,91]. It is a commercial model based on the application of alerts and reasoning rules which covers alerts for a variety of toxicological endpoints. An alert consists of a toxicophore (a substructure known or thought to be responsible for the toxicity) and is associated with literature references, comments and examples from toxicological experts. The rules are based either on hypotheses relating to mechanisms of action of a chemical class or on observed empirical relationships. The final toxicity assessment is a result of a two-part process: (i) the program checks whether any alerts from the knowledge base appear in the query compounds, and (ii) the reasoning model is applied in order to determine the likelihood of the compound's toxicity (expressed as the level of likelihood) [92]. In the present study, the endpoints assessed were chromosomal aberrations (in vitro; in vivo), mutagenicity (in vitro for bacterium and mammals; in vivo) and nonspecific genotoxicity (in vitro; in vivo). Prediction results ranging from "plausible" to "certain" were considered as mutagenic, whereas results from "inactive" to "doubted" were considered as non-mutagenic. The prediction "equivocal" was kept as a separate group. In the case of inactive predictions (query structure does not match any structural alerts or examples in Derek which show activity in a bacterial reverse mutation assay), DEREK Nexus ${ }^{\circledR}$ also provided information of misclassified or unclassified features. Misclassified refers to features in the molecule that are found in non-alerting mutagens in the Lhasa reference data, while unclassified refers to features that have not been found in the reference set. In the present study, the label "no prediction" was used for endpoints not firing any alerts at the selected reasoning level.

\subsubsection{VEGA QSAR@}

The free VEGA QSAR ${ }^{\circledR}$ platform (Version 1.1.5., Mario Negri Institute, Milan, Italy [93] was the second tool employed for Phase 1 . For the current analysis, four available mutagenicity models were used: CAESAR 2.1.13; SarPy/IRFMN 1.0.7; ISS 1.0.2; KNN/Readacross 1.0.0. All models provided a qualitative class label for each mycotoxin evaluated: non-mutagenic, mutagenic and suspected to be mutagenic. These class labels were provided for both prediction and experimental outputs [93].

The level of prediction reliability was also estimated. For that purpose, the VEGA independent algorithm (Consensus 1.0.2 based on read across) was used. This algorithm works on all the separate models. Concretely, it assesses three models' pillars related to: (i) the property (mutagenicity) to be studied (concordance, accuracy and structural alerts), (ii) chemical information (similarity) and (iii) function linking the property and the chemical (algorithm). The resulting parameters of the elements assessed are merged into the applicability of domain (AD) and are classified as into, out and could out of domain. In order to evaluate the $\mathrm{AD}$ of the models, two methods were also gathered by VEGA: (i) the descriptors range check (DRC) that evaluates if the descriptors of the target compound has values in the range of those related to the substances in the training set (TS), and (ii) atom-centred fragments $(\mathrm{ACF})$ an index that takes into account the presence of one or more fragments that are not found in the model TS, or that are rare fragments. The applicability of domain index (ADI) could be expressed in a quantitative (numerical) value from 0 to 1 -equal to a compound in the training set of the model—of each model for a particular compound [93]. In order to characterize both indexes, consider the profile of fundamental physicochemical properties of the training set compounds as well as their structural features and mechanistic disposition [94] In the present study, the AD and ADI values were first evaluated. If ADI $>0.8$ and $\mathrm{AD}$ was into the applicability of domain, 
the prediction was considered to be strongly supported [93]. If both conditions were not fulfilled, the other reliability parameters were assessed: similarity (Sim) with the two/three most similar compounds in the training set (TS), accuracy (Acc) in the prediction for the two/three most similar compounds in TS and concordance (Cc) between the predicted value and the experimental values of the three or two (depends on different models) most similar compounds in the model TS.

Results are expressed in a quantitative way ( 0 to 1$)$ for ADI and qualitative way for AD (into, out, could out) and for DRC (true, false). Reliability of the prediction, based on the overall results obtained, is expressed as good, low and moderate.

Special emphasis was given to the concordance of the experimental output retrieved from each model and the prediction. Additionally, the presence of structural alerts (SA) provided by the ISS model and mutagenicity relevant substructures (SM) provided by SarPy/IRFMN model were considered.

\subsection{In Vitro Genotoxicity Screening (Phase 2)}

\subsubsection{Exposure Concentrations and Solubility Test}

All stock solutions were prepared in DMSO, except FB1 which was dissolved in water. The selected maximum concentration to be tested in the SOS/umu assay was $40 \mathrm{mg} / \mathrm{mL}$ (corresponding to $1000 \mu \mathrm{g} / \mathrm{mL}$ in the 96-well plate). For insoluble substances, the highest soluble concentration was used. Insolubility was assessed as precipitation (or turbidity) in the solvent and evident to the unaided eye over a dark background. For very soluble mycotoxins (NIV, 3ADON, 15ADON, T-2, HT-2) that were not toxic for bacteria and induced an equivocal response, two extra concentrations were also tested: 160 and $80 \mathrm{mg} / \mathrm{mL}$ (corresponding to 4000 and $2000 \mu \mathrm{g} / \mathrm{mL}$ in the 96-well plate, respectively). The positive control stock solutions were prepared in DMSO: at $500 \mu \mathrm{g} / \mathrm{mL}(12.5 \mu \mathrm{g} / \mathrm{mL}$ in 96- well plate) for 2-aminoanthracene (2-AA) (Sigma-Aldrich, Germany) and at $100 \mu \mathrm{g} / \mathrm{mL}$ $(2.5 \mu \mathrm{g} / \mathrm{mL})$ for 4-nitroquinoline- $n$-oxide (4-NQO) (Sigma-Aldrich, China). 4NQO was the positive control without metabolic activation (PBS) and 2AA with metabolic activation (S9).

\subsubsection{SOS/Umu Test}

The SOS/umu test was performed according to the method proposed by [62,63], with some modifications.

The test strain Salmonella typhimurium 1535/pSK1002 (German Collection for microorganisms and cell cultures (DSMZ) ) was thawed from stock $\left(-135^{\circ} \mathrm{C}\right.$ in TGA medium containing $10 \%$ of DMSO as cryoprotective agent) and $0.5 \mathrm{~mL}$ of bacteria were suspended in $100 \mathrm{~mL}$ TGA medium supplemented with ampicillin $(50 \mu \mathrm{g} / \mathrm{mL})$. The bacteria culture was incubated overnight at $37^{\circ} \mathrm{C}$ with slight orbital shaking (155 rpm) from $15-17 \mathrm{~h}$ until an optimal orbital density $\left(\mathrm{OD}_{600}\right.$ from 0.5 to 1.5$)$ was reached. Then, the overnight culture was diluted with fresh TGA medium (not supplemented with ampicillin) and incubated for $2 \mathrm{~h}$ at $37^{\circ} \mathrm{C}$ with orbital shaking (155 rpm), in order to obtain a log-phase bacterial growth culture $\left(\mathrm{OD}_{600}\right.$ from 0.15 to 0.4$)$. The test was performed in the absence (PBS) and presence of an external metabolic activation system (10\% of rat S9 mix, prepared from S9 $\mathrm{SD}$ rat liver Aroclor $\mathrm{KCl}$ frozen, Trinova, Germany) in order to also determine the possible genotoxic effects of any metabolite. In each test performed, negative and positive controls were included, DMSO (or water for FB1) was used as solvent control (negative control), and 4-NQO and 2-AA were used as positive controls in the absence and presence of S9 mix, respectively (see maximum concentrations used in Section 5.3.1)

The test procedure was as follows: first, mycotoxins were dissolved at their respective maximum concentrations (see Section 5.3.1). Then, 11 serial $\frac{1}{2}$ dilutions in DMSO (or water for FB1) of mycotoxins and positive controls were prepared in a 96-well plate (plate A). The final volume in each well was $10 \mu \mathrm{L}$. The wells on the last row of the plate contained the negative control (DMSO or water). 
Afterwards, $70 \mu \mathrm{L}$ water was added to each well. At this point each well was checked in order to detect any precipitation of the mycotoxins.

Thereafter, in another two 96-well plates (plates B; one for the test with S9 and the other without S9), $10 \mu \mathrm{L}$ S9 mix or $10 \mu \mathrm{L}$ PBS, respectively, were added, followed by $25 \mu \mathrm{L}$ of the concentrations of the different mycotoxins previously prepared (plate A). Finally, $90 \mu \mathrm{L} /$ well of exponentially growing bacteria suspension was added to both plates and incubated for $4 \mathrm{~h}$ at $37^{\circ} \mathrm{C}$ with orbital shaking (500 rpm). After the incubation period, $\mathrm{A}_{600}$ was measured to evaluate toxicity (two plates B). Toxicity was calculated as follows:

$$
\% \text { Survival }=\frac{A_{600} \text { for each concentration tested }}{\text { Average } A_{600} \text { for negative control }} \times 100
$$

Afterwards, for the determination of $\beta$-galactosidase activity, $30 \mu \mathrm{L} /$ well of treatment plates (plate B) were transferred into two new 96-well plates (plates $C$ ) containing $150 \mu \mathrm{L} /$ well of ONPG solution (2-nitrophenyl- $\beta$-D-galactopyranoside, Sigma-Aldrich, Switzerland): $0.9 \mathrm{mg} / \mathrm{mL}$ in B-buffer was prepared according to [63] for an enzymatic reaction. Plates $\mathrm{C}$ were incubated for $30 \mathrm{~min}$ at $28^{\circ} \mathrm{C}$ with orbital shaking $(500 \mathrm{rpm}$ ) in the dark. After the incubation period, the reaction was stopped after adding $120 \mu \mathrm{L} /$ well of $\mathrm{Na}_{2} \mathrm{CO}_{3}(1 \mathrm{M})$. Finally, $\mathrm{A}_{420}$ was measured and $\beta$-galactosidase activity was determined as follows (two plates $\mathrm{C}$ ):

$\beta$-galactosidase activity relative units (RU):

$$
\mathrm{RU}:=\frac{\mathrm{A}_{420} \text { for each concentration tested }}{\mathrm{A}_{600} \text { for each concentration tested }}
$$

Additionally, induction factor (IF)

$$
\mathrm{IF}=\frac{\mathrm{RU} \text { for each concentration tested }}{\text { Average } \mathrm{RU} \text { for negative control }}
$$

where average $\beta$-galactosidase RU for negative control:

$$
\mathrm{RU}:=\frac{\text { Average } \mathrm{A}_{420} \text { for negative control }}{\text { Average } \mathrm{A}_{600} \text { for negative control }}
$$

Supplementary Materials: The following are available online at https:/ / www.mdpi.com/article / 10.3390/toxins13100734/s1, Table S1, Descriptors calculated for analyzed mycotoxins. Figure S1: Results from SOS/umu test with (dark grey) or without S9 (light grey) activation for NIV, 3-ADON, 15-ADON, T-2 and HT-2 toxins at the highest soluble concentration $(4000 \mu \mathrm{g} / \mathrm{mL})$, Table S2: Structural alerts for CAESAR Model, Table S3: Structural alerts for SarPy/IRFMN Model, Table S4: Structural alerts for ISS Model.

Author Contributions: Conceptualization, A.L.d.C. and A.V.; Data curation, M.F.; Formal analysis, M.A.-J., M.F. and A.V.; Funding acquisition, E.G.-P., A.L.d.C. and A.V.; Methodology, M.A.-J., M.F. and A.V.; Supervision, A.V.; Writing—original draft, M.A.-J., M.F. and A.V.; Writing—review \& editing, E.G.-P., A.L.d.C. and A.V. All authors have read and agreed to the published version of the manuscript.

Funding: This work was funded by the Spanish "Ministerio de Economía, Industria y Competitividad, Agencia Estatal de Investigación” (AGL2017-85732-R) (MINECO/AEI/FEDER, UE).

Institutional Review Board Statement: Not applicable.

Informed Consent Statement: Not applicable.

Data Availability Statement: Data is contained within the article.

Conflicts of Interest: The authors declare no conflict of interest. 


\section{References}

1. Bennett, J.W.; Klich, M. Mycotoxins. Clin. Microbiol. Rev. 2003, 16, 497-516. [CrossRef] [PubMed]

2. European Commission (EC). Commission Regulation (EC) No 1881 of 19 of December 2006 Setting Maximum Levels for Certain Contaminants in Foodstuffs (Text with EEA Relevance); European Commission: Brussels, Belgium, 2006; pp. 1-20.

3. Logrieco, A.F.; Miller, J.D.; Eskola, M.; Krska, R.; Ayalew, A.; Bandyopadhyay, R.; Battilani, P.; Bhatnagar, D.; Chulze, S.; De Saeger, S.; et al. The Mycotox Charter: Increasing Awareness of, and Concerted Action for, Minimizing Mycotoxin Exposure Worldwide. Toxins 2018, 10, 149. [CrossRef] [PubMed]

4. Eskola, M.; Kos, G.; Elliott, C.T.; Hajšlová, J.; Mayar, S.; Krska, R. Worldwide contamination of food-crops with mycotoxins: Validity of the widely cited "FAO estimate" of 25\%. Crit. Rev. Food. Sci. Nutr. 2020, 60, 2773-2789. [CrossRef] [PubMed]

5. Maggiore, A.; Afonso, A.; Barrucci, F.; Sanctis, G.D.; EFSA (European Food Safety Authority). Climate change as a driver of emerging risks for food and feed safety, plant, animal health and nutritional quality. EFSA Support. Publ. 2020, 17, 146. [CrossRef]

6. Battilani, P.; Toscano, P.; Van Der Fels-Klerx, H.J.; Moretti, A.; Leggieri, M.C.; Brera, C.; Rortais, A.; Goumperis, T.; Robinson, T. Aflatoxin B1 contamination in maize in Europe increases due to climate change. Sci. Rep. 2016, 6, 24328. [CrossRef]

7. Penagos-Tabares, F.; Khiaosa-Ard, R.; Nagl, V.; Faas, J.; Jenkins, T.; Sulyok, M.; Zebeli, Q. Mycotoxins, Phytoestrogens and Other Secondary Metabolites in Austrian Pastures: Occurrences, Contamination Levels and Implications of Geo-Climatic Factors. Toxins 2021, 13, 460. [CrossRef]

8. IARC. Chemical agents and related occupations. Monogr. Eval. Carcinog. Risks Hum. 2012, 100 F, $225-248$.

9. EFSA (European Food Safety Authority). Scientific Opinion on the risks for public health related to the presence of zearalenone in food. EFSA J. 2011, 9, 2197. [CrossRef]

10. EFSA (European Food Safety Authority); Knutsen, H.K.; Alexander, J.; Barregård, L.; Bignami, M.; Brüschweiler, B.; Ceccatelli, S.; Cottrill, B.; Dinovi, M.; Grasl-Kraupp, B.; et al. Risks to human and animal health related to the presence of deoxynivalenol and its acetylated and modified forms in food and feed. EFSA J. 2017, 15, 4718. [CrossRef]

11. Arce-López, B.; Lizarraga, E.; Vettorazzi, A.; González-Peñas, E. Human Biomonitoring of Mycotoxins in Blood, Plasma and Serum in Recent Years: A Review. Toxins 2020, 12, 147. [CrossRef]

12. Smith, M.-C.; Madec, S.; Coton, E.; Hymery, N. Natural Co-Occurrence of Mycotoxins in Foods and Feeds and Their in vitro Combined Toxicological Effects. Toxins 2016, 8, 94. [CrossRef] [PubMed]

13. Alonso-Jáuregui, M.; López de Cerain, A.; González-Peñas, E.; Vettorazzi, A. Chapter 1: Combined Toxicity of Aflatoxins and Ochratoxin A. In Aflatoxins: Biochemistry, Toxicology, Public Health, Policies and Modern Methods of Analysis; Nova Science Publishers: New York, NY, USA, 2019; pp. 3-28.

14. National Toxicology Program (NTP). Toxicology and Carcinogenesis Studies of Ochratoxin A (CAS No. 303-47-9) in F344/N Rats. Natl. Toxicol. Program. Tech. Rep. Ser. 1989, 358, 1-142.

15. Ruan, H.; Lu, Q.; Wu, J.; Qin, J.; Sui, M.; Sun, X.; Shi, Y.; Luo, J.; Yang, M. Hepatotoxicity of food-borne mycotoxins: Molecular mechanism, anti-hepatotoxic medicines and target prediction. Crit. Rev. Food Sci. Nutr. 2021, 1-28. [CrossRef]

16. Li, L.; Zhang, T.; Ren, X.; Li, B.; Wang, S. Male reproductive toxicity of zearalenone-meta-analysis with mechanism review. Ecotoxicol. Environ. Saf. 2021, 221, 112457. [CrossRef]

17. Chen, J.; Wei, Z.; Wang, Y.; Long, M.; Wu, W.; Kuca, K. Fumonisin B1: Mechanisms of toxicity and biological detoxification progress in animals. Food Chem. Toxicol. 2021, 149, 111977. [CrossRef] [PubMed]

18. Wang, S.; Wu, K.; Xue, D.; Zhang, C.; Rajput, S.A.; Qi, D. Mechanism of deoxynivalenol mediated gastrointestinal toxicity: Insights from mitochondrial dysfunction. Food Chem. Toxicol. 2021, 153, 112214. [CrossRef]

19. Pickova, D.; Ostry, V.; Toman, J.; Malir, F. Aflatoxins: History, Significant Milestones, Recent Data on Their Toxicity and Ways to Mitigation. Toxins 2021, 13, 399. [CrossRef] [PubMed]

20. Ames, B.N.; Durston, W.E.; Yamasaki, E.; Lee, F.D. Carcinogens are Mutagens: A Simple Test System Combining Liver Homogenates for Activation and Bacteria for Detection. Proc. Natl. Acad. Sci. USA 1973, 70, 2281-2285. [CrossRef]

21. McCann, J.; Spingarn, N.E.; Kobori, J.; Ames, B.N. Detection of carcinogens as mutagens: Bacterial tester strains with R factor plasmids. Proc. Natl. Acad. Sci. USA 1975, 72, 979-983. [CrossRef]

22. Wong, J.J.; Hsieh, D.P. Mutagenicity of aflatoxins related to their metabolism and carcinogenic potential. Proc. Natl. Acad. Sci. USA 1976, 73, 2241-2244. [CrossRef]

23. Tang, T.; Friedman, M.A. Carcinogen activation by human liver enzymes in the ames mutagenicity test. Mutat. Res. Mutagen. Relat. Subj. 1977, 46, 387-394. [CrossRef]

24. Kuczuk, M.H.; Benson, P.M.; Heath, H.; Hayes, A.W. Evaluation of the mutagenic potential of mycotoxins using Salmonella typhimurium and Saccharomyces cerevisiae. Mutat. Res. Mutagen. Relat. Subj. 1978, 53, 11-20. [CrossRef]

25. Wehner, F.C.; Marasas, W.F.O.; Thiel, P.G. Lack of mutagenicity to Salmonella typhimurium of some Fusarium mycotoxins. Appl. Environ. Microbiol. 1978, 35, 659-662. [CrossRef] [PubMed]

26. Wehner, F.; Thiel, P.; Van Rensburg, S.; Demasius, I.P. Mutagenicity to Salmonella typhimurium of some Aspergillus and Penicillium mycotoxins. Mutat. Res. Toxicol. 1978, 58, 193-203. [CrossRef]

27. Lee, L.S.; Dunn, J.J.; Delucca, A.J.; Ciegler, A. Role of lactone ring of aflatoxin B1 in toxicity and mutagenicity. Cell. Mol. Life Sci. 1981, 37, 16-17. [CrossRef]

28. Wheeler, L. A comparison of aflatoxin B1-induced cytotoxicity, mutagenicity and prophage induction in Salmonella typhimurium mutagen tester strains TA1535, TA1538, TA98 and TA100. Mutat. Res. Mol. Mech. Mutagen. 1981, 83, 39-48. [CrossRef] 
29. Beaune, P.; Lemestré-Cornet, R.; Kremers, P.; Albert, A.; Gielen, J. The Salmonella/mammalian microsome mutagenicity test: Comparison of human and rat livers as activating systems. Mutat. Res. Toxicol. 1985, 156, 139-146. [CrossRef]

30. Auffray, Y.; Boutibonnes, P. Evaluation of the genotoxic activity of some mycotoxins using Escherichia coli in the SOS spot test. Mutat. Res. Toxicol. 1986, 171, 79-82. [CrossRef]

31. Auffray, Y.; Boutibonnes, P. Induction of SOS function inEscherichia coli by some mycotoxins. Environ. Toxicol. Water Qual. 1988, 3, 371-378. [CrossRef]

32. Reis, J. Detection of genotoxic properties of mycotoxins with the SOS chromotest. Naturwissenschaften 1986, 73, 677-678. [CrossRef]

33. Krivobok, S.; Olivier, P.; Marzin, D.; Seigle-Murandi, F.; Steiman, R. Study of the genotoxic potential of 17 mycotoxins with the SOS Chromotest. Mutagenesis 1987, 2, 433-439. [CrossRef]

34. Nakamura, S.; Oda, Y.; Shimada, T.; Oki, I.; Sugimoto, K. SOS-inducing activity of chemical carcinogens and mutagens in Salmonella typhimurium TA1535/pSK1002: Examination with 151 chemicals. Mutat. Res. Lett. 1987, 192, 239-246. [CrossRef]

35. Foster, P.L.; Groopman, J.D.; Eisenstadt, E. Induction of base substitution mutations by aflatoxin B1 is mucAB dependent in Escherichia coli. J. Bacteriol. 1988, 170, 3415-3420. [CrossRef] [PubMed]

36. Sambamurti, K.; Callahan, J.; Luo, X.; Perkins, C.P.; Jacobsen, J.S.; Humayun, M.Z. Mechanisms of mutagenesis by a bulky DNA lesion at the guanine N7 position. Genetics 1988, 120, 863-873. [CrossRef] [PubMed]

37. Baertschi, S.W.; Raney, K.D.; Shimada, T.; Harris, T.M.; Guengerich, F.P. Comparison of rates of enzymic oxidation of aflatoxin B1, aflatoxin G1, and sterigmatocystin and activities of the epoxides in forming guanyl-N7 adducts and inducing different genetic responses. Chem. Res. Toxicol. 1989, 2, 114-122. [CrossRef] [PubMed]

38. Sakai, M.; Abe, K.-I.; Okumura, H.; Kawamura, O.; Sugiura, Y.; Horie, Y.; Ueno, Y. Genotoxicity of fungi evaluated by SOS microplate assay. Nat. Toxins 1992, 1, 27-34. [CrossRef]

39. Bailey, E.A.; Iyer, R.S.; Stone, M.; Harris, T.M.; Essigmann, J.M. Mutational properties of the primary aflatoxin B1-DNA adduct. Proc. Natl. Acad. Sci. USA 1996, 93, 1535-1539. [CrossRef]

40. Shimada, T.; Hayes, C.L.; Yamazaki, H.; Amin, S.; Hecht, S.S.; Guengerich, F.P.; Sutter, T.R. Activation of chemically diverse procarcinogens by human cytochrome P-450 1B1. Cancer Res. 1996, 56, 2979-2984.

41. IARC. Monographs on the Evaluation of the Carcinogenic Risk of Chemicals to Man: Some Naturally Occurring Substances; IARC: Lyon, France, 1976; Volume 10, pp. 1-353.

42. Ueno, Y. Mode of action of trichothecenes. Pergamon 1978, 49, 1737-1745. [CrossRef]

43. Shimada, T.; Yamazaki, H.; Mimura, M.; Guengerich, F. Rat pulmonary microsomal cytochrome P-450 enzymes involved in the activation of procarcinogens. Mutat. Res. Mol. Mech. Mutagen. 1992, 284, 233-241. [CrossRef]

44. IARC. Some Naturally Occurring Substances: Food Items and Constituents, Heterocyclic Aromatic Amines and Mycotoxins. Monogr. Eval. Carcinog. Risks Hum. 1993, 56, 397-444.

45. Knasmüller, S.; Bresgen, N.; Kassie, F.; Mersch-Sundermann, V.; Gelderblom, W.; Zöhrer, E.; Eckl, P. Genotoxic effects of three Fusarium mycotoxins, fumonisin B1, moniliformin and vomitoxin in bacteria and in primary cultures of rat hepatocytes. Mutat. Res. Toxicol. Environ. Mutagen. 1997, 391, 39-48. [CrossRef]

46. Takakura, N.; Nesslany, F.; Fessard, V.; Le Hegarat, L. Absence of in vitro genotoxicity potential of the mycotoxin deoxynivalenol in bacteria and in human TK6 and HepaRG cell lines. Food Chem. Toxicol. 2014, 66, 113-121. [CrossRef]

47. Bendele, A.; Neal, S.; Oberly, T.; Thompson, C.; Bewsey, B.; Hill, L.; Rexroat, M.; Carlton, W.; Probst, G. Evaluation of ochratoxin A for mutagenicity in a battery of bacterial and mammalian cell assays. Food Chem. Toxicol. 1985, 23, 911-918. [CrossRef]

48. Zepnik, H. Ochratoxin A-Induced Tumor Formation: Is There a Role of Reactive Ochratoxin A Metabolites? Toxicol. Sci. 2001, 59, 59-67. [CrossRef]

49. Föllmann, W.; Lucas, S. Effects of the mycotoxin ochratoxin A in a bacterial and a mammalian in vitro mutagenicity test system. Arch. Toxicol. 2003, 19, 298-304. [CrossRef] [PubMed]

50. Obrecht-Pflumio, S.; Chassat, T.; Dirheimer, G.; Marzin, D. Genotoxicity of ochratoxin A by Salmonella mutagenicity test after bioactivation by mouse kidney microsomes. Mutat. Res. Toxicol. Environ. Mutagen. 1999, 446, 95-102. [CrossRef]

51. Malaveille, C.; Brun, G.; Bartsch, H. Structure-activity studies in E. coli strains on ochratoxin A (OTA) and its analogues implicate a genotoxic free radical and a cytotoxic thiol derivative as reactive metabolites 氺. Mutat. Res. Mol. Mech. Mutagen. 1994, 307, 141-147. [CrossRef]

52. Bartholomew, R.M.; Ryan, D.S. Lack of mutagenicity of some phytoestrogens in the Salmonella/mammalian microsome assay. Mutat. Res. Toxicol. 1980, 78, 317-321. [CrossRef]

53. Ghédira-Chékir, L.; Maaroufi, K.; Zakhama, A.; Ellouz, F.; Dhouib, S.; Creppy, E.; Bacha, H. Induction of a SOS repair system in lysogenic bacteria by zearalenone and its prevention by vitamin E. Chem. Biol. Interact. 1998, 113, 15-25. [CrossRef]

54. IARC. Monographs on the Evaluation of Carcinogenic Risks To Humans. IARC Monogr. Eval. Carcinog. Risks Hum. 2002, 96, $1-390$.

55. Park, D.L.; Rua, S.M.; Mirocha, C.J.; Abd-Alla, E.-S.; Weng, C.Y. Mutagenic potentials of fumonisin contaminated corn following ammonia decontamination procedure. Mycopathologia 1992, 117, 105-108. [CrossRef]

56. Aranda, M.; Pérez-Alzola, L.; Ellahueñe, M.F.; Sepúlveda, C. Assessment of in vitro mutagenicity in Salmonella and in vivo genotoxicity in mice of the mycotoxin fumonisin B(1). Mutagenesis 2000, 15, 469-471. [CrossRef]

57. ICH. Harmonised Guideline Assessment and Control of DNA Reactive (Mutagenic) Impurities in Pharmaceuticals To Limit Potential Carcinogenic Risk M7(R1); ICH: Geneva, Switzerland, 2017; Volume 7. 
58. ICH. Guideline S2 (R1) on Genotoxicity Testing and Data Interpretation for Pharmaceuticals Intended for Human Use; ICH: Geneva, Switzerland, 2008; Volume 2, pp. 1-28.

59. EFSA (European Food Safety Authority). Scientific opinion on genotoxicity testing strategies applicable to food and feed safety assessment. EFSA J. 2011, 9, 1-68. [CrossRef]

60. OECD. Test. No. 471: Bacterial Reverse Mutation Test.; (OECD Guidelines for the Testing of Chemicals, Section 4); OECD: Paris, France, 2020; pp. 1-24. [CrossRef]

61. OECD. Test No. 487: In Vitro Mammalian Cell Micronucleus Test; (OECD Guidelines for the Testing of Chemicals, Section 4); OECD: Paris, France, 2016; pp. 1-29. [CrossRef]

62. Oda, Y.; Nakamura, S.; Oki, I.; Kato, T.; Shinagawa, H. Evaluation of the new system (umu-test) for the detection of environmental mutagens and carcinogens. Mutat. Res. Mutagen. Relat Subj. 1985, 147, 219-229. [CrossRef]

63. Reifferscheid, G.; Heil, J.; Oda, Y.; Zahn, R. A microplate version of the SOS/umu-test for rapid detection of genotoxins and genotoxic potentials of environmental samples. Mutat. Res. Mutagen. Relat. Subj. 1991, 253, 215-222. [CrossRef]

64. Reifferscheid, G.; Heil, J. Validation of the SOS/umu test using test results of 486 chemicals and comparison with the Ames test and carcinogenicity data. Mutat. Res. Toxicol. 1996, 369, 129-145. [CrossRef]

65. Weaver, S.; Gleeson, M.P. The importance of the domain of applicability in QSAR modeling. J. Mol. Graph. Model. 2008, 26, 1315-1326. [CrossRef]

66. EFSA (European Food Safety Authority); Donohoe, T.; Garnett, K.; Lansink, A.O.; Afonso, A.; Noteborn, H. Emerging risks identification on food and feed-EFSA. EFSA J. 2018, 16, 5359. [CrossRef]

67. Van Bossuyt, M.; Van Hoeck, E.; Raitano, G.; Vanhaecke, T.; Benfenati, E.; Mertens, B.; Rogiers, V. Performance of In Silico Models for Mutagenicity Prediction of Food Contact Materials. Toxicol. Sci. 2018, 163, 632-638. [CrossRef]

68. Ferrari, T.; Gini, G. An open source multistep model to predict mutagenicity from statistical analysis and relevant structural alerts. Chem. Cent. J. 2010, 4, S2. [CrossRef]

69. Xu, C.; Cheng, F.; Chen, L.; Du, Z.; Li, W.; Liu, G.; Lee, P.W.; Tang, Y. In silico Prediction of Chemical Ames Mutagenicity. J. Chem. Inf. Model. 2012, 52, 2840-2847. [CrossRef]

70. Benigni, R.; Battistelli, C.L.; Bossa, C.; Tcheremenskaia, O.; Crettaz, P. New perspectives in toxicological information management, and the role of ISSTOX databases in assessing chemical mutagenicity and carcinogenicity. Mutagenesis 2013, 28, 401-409. [CrossRef]

71. Vian, M.; Raitano, G.; Roncaglioni, A.; Benfenati, E. In silico model for mutagenicity (Ames test), taking into account metabolism. Mutagenesis 2019. [CrossRef]

72. Hillebrecht, A.; Muster, W.; Brigo, A.; Kansy, M.; Weiser, T.; Singer, T. Comparative Evaluation of in SilicoSystems for Ames Test Mutagenicity Prediction: Scope and Limitations. Chem. Res. Toxicol. 2011, 24, 843-854. [CrossRef] [PubMed]

73. McDaniels, A.E.; Reyes, A.L.; Wymer, L.J.; Rankin, C.C.; Stelma, G.N. Comparison of the Salmonella (Ames) test, Umu tests, and the sos chromotests for detecting genotoxins. Environ. Mol. Mutagen. 1990, 16, 204-215. [CrossRef] [PubMed]

74. EFSA (European Food Safety Authority); Schrenk, D.; Bignami, M.; Bodin, L.; Chipman, J.K.; del Mazo, J.; Grasl-Kraupp, B.; Hogstrand, C.; Hoogenboom, L.; Leblanc, J.-C.; et al. Risk assessment of aflatoxins in food. EFSA J. 2020, 18, 6040. [CrossRef]

75. EFSA (European Food Safety Authority). Opinion of the Sscientific Panel on Contaminants in the Food Chain on a request from the Commission related to the potential increase of consumer health risk by a possible increase of the existing maximum levels for aflatoxins in almonds, hazelnuts and pistachios and derived products. EFSA J. 2007, 446, 1-127. [CrossRef]

76. Díaz Nieto, C.H.; Granero, A.M.; Zon, M.A.; Fernández, H. Sterigmatocystin: A mycotoxin to be seriously considered. Food Chem. Toxicol. 2018, 118, 460-470. [CrossRef]

77. Theumer, M.; Henneb, Y.; Khoury, L.; Snini, S.; Tadrist, S.; Canlet, C.; Puel, O.; Oswald, I.; Audebert, M. Genotoxicity of aflatoxins and their precursors in human cells. Toxicol. Lett. 2018, 287, 100-107. [CrossRef]

78. EFSA (European Food Safety Authority). Scientific Opinion on the risk for public and animal health related to the presence of sterigmatocystin in food and feed. EFSA J. 2013, 11, 3254. [CrossRef]

79. EFSA (European Food Safety Authority); Schrenk, D.; Bodin, L.; Chipman, J.K.; del Mazo, J.; Grasl-Kraupp, B.; Hogstrand, C.; Hoogenboom, L.; Leblanc, J.-C.; Nebbia, C.S.; et al. Risk assessment of ochratoxin A in food. EFSA J. 2020, 18, 6113. [CrossRef]

80. Mostrom, M.S.; Raisbeck, M.F. Trichothecenes. In Veterinary Toxicology; Elsevier: Amsterdam, The Netherlands, 2007; pp. 951-976.

81. McCormick, S.P.; Stanley, A.M.; Stover, N.A.; Alexander, N.J. Trichothecenes: From Simple to Complex Mycotoxins. Toxins 2011, 3, 802-814. [CrossRef] [PubMed]

82. EFSA (European Food Safety Authority). Scientific Opinion on the risks for animal and public health related to the presence of T-2 and HT-2 toxin in food and feed. EFSA J. 2011, 19, 2481. [CrossRef]

83. EFSA (European Food Safety Authority); Le Hégarat, L.; Takakura, N.; Simar, S.; Nesslany, F.; Fessard, V. The in vivo genotoxicity studies on nivalenol and deoxynivalenol. EFSA Support. Publ. 2014, 11, 1-33. [CrossRef]

84. EFSA (European Food Safety Authority). Scientific Opinion on risks for animal and public health related to the presence of nivalenol in food and feed. EFSA J. 2013, 11, 3262. [CrossRef]

85. Rogowska, A.; Pomastowski, P.; Sagandykova, G.; Buszewski, B. Zearalenone and its metabolites: Effect on human health, metabolism and neutralisation methods. Toxicon 2019, 162, 46-56. [CrossRef]

86. EFSA (European Food Safety Authority). Opinion of the Scientific Panel on contaminants in the food chain [CONTAM] related to fumonisins as undesirable substances in animal feed. EFSA J. 2005, 3, 235. [CrossRef] 
87. EFSA (European Food Safety Authority); Knutsen, H.-K.; Barregård, L.; Bignami, M.; Brüschweiler, B.; Ceccatelli, S.; Cottrill, B.; Dinovi, M.; Edler, L.; Grasl-Kraupp, B.; et al. Appropriateness to set a group health-based guidance value for fumonisins and their modified forms. EFSA J. 2018, 16, 5172. [CrossRef]

88. Hideo, S.; Takeshi, K.; Tsuneo, I.; Kozo, M.; Atsuo, N. Cloning and characterization of the umu operon responsible for inducible mutagenesis in Escherichia coli. Gene 1983, 23, 167-174. [CrossRef]

89. Ductless Fume Hoods Classic Range ICRUMA. Available online: https:/ / cruma.es/en/ductless-fume-hoods-classic-range/ (accessed on 3 June 2020).

90. Lhasa Limited. ICH M7 Prediction. Available online: https://www.lhasalimited.org/ich-m7.htm (accessed on 13 November 2019).

91. Marchant, C.A.; Briggs, K.A.; Long, A. In Silico Tools for Sharing Data and Knowledge on Toxicity and Metabolism: Derek for Windows, Meteor, and Vitic. Toxicol. Mech. Methods 2008, 18, 177-187. [CrossRef] [PubMed]

92. Worth, A.; Lapenna, S.; Lo Piparo, E.; Mostrag-Szlichtyng, A.; Serafimova, R. The Applicability of Software Tools for Genotoxicity and Carcinogenicity Prediction: Case Studies Relevant to the Assessment of Pesticides; JRC Scientific and Technical Reports; EC Joint Research Centre Institute for Health and Consumer Protection: Ispra, Italy, 2010; pp. 18-19. [CrossRef]

93. Benfenati, E.; Manganaro, A.; Gini, G. VEGA-QSAR: AI inside a platform for predictive toxicology. In Proceedings of the Popularize Artificial Intelligence 2013, CEUR, Turing, Italy, 5 December 2013; Volume 1107, pp. 21-28.

94. Kühne, R.; Ebert, R.-U.; Schüürmann, G. Chemical Domain of QSAR Models from Atom-Centered Fragments. J. Chem. Inf. Model. 2009, 49, 2660-2669. [CrossRef] [PubMed] 